\title{
Phosphate Adsorption by Montmorillonites Modified with Lanthanum/Iron and a Laboratory Test using Water from the Jacarepaguá Lagoon (RJ, Brazil)
}

\author{
Laís F. de Castro, ${ }^{\circledR a, b}$ Vitor S. Brandão, ${ }^{c}$ Luiz C. Bertolino, ${ }^{c}$ Weber F. L. de Souza ${ }^{a}$ and \\ Viviane G. Teixeira*,b \\ ${ }^{a}$ Instituto Nacional de Tecnologia (INT), Ministério da Ciência, Tecnologia, \\ Inovações e Comunicações (MCTIC), Av. Venezuela, 82, 20081-312 Rio de Janeiro-RJ, Brazil \\ ${ }^{b}$ Departamento de Química Analítica, Instituto de Química, Universidade Federal do Rio de Janeiro, \\ Av. Athos da Silveira Ramos, 149, 21941-909 Rio de Janeiro-RJ, Brazil \\ ${ }^{c}$ Centro de Tecnologia Mineral (CETEM), Ministério da Ciência, Tecnologia, \\ Inovações e Comunicações (MCTIC), Av. Pedro Calmon, 900, 21941-908 Rio de Janeiro-RJ, Brazil
}

\begin{abstract}
Montmorillonites modified with lanthanum(III) and iron(III) were prepared from two commercial clays. These materials were characterized by powder X-ray diffraction analysis, X-ray fluorescence, infrared spectroscopy, $\mathrm{N}_{2}$ adsorption, and scanning electron microscopy. The incorporation of lanthanum(III) and iron(III) varied from 0 to $4.00 \%$. The amount of these cations governed the adsorption capacity of the material since an increase in the percentage of La by 1.7 times improved the adsorption capacity by 3.3 times. The structural properties of the precursor clay minerals, such as pore size, may have influenced the extension of the modification process. Kinetics and equilibrium studies indicated that adsorption occurs mainly within $24 \mathrm{~h}$, and the pseudo-second order and Lagmuir models described the process. The phosphate adsorption capacity ranged from 2.86 to $17.86 \mathrm{mg} \mathrm{g}^{-1}$ for the modified materials and was mainly dependent on the La content. A laboratory test with a natural water sample from the Jacarepaguá Lagoon showed reduction of the soluble reactive phosphorus concentration from 0.41 to $0.04 \mathrm{mg} \mathrm{L}^{-1}$, for the material with $4.00 \% \mathrm{La}_{2} \mathrm{O}_{3}$. The materials described in this work were effective for the reduction of the soluble reactive phosphate, contributing to the research of a national product destined to the restoration of eutrophic aquatic environments.
\end{abstract}

Keywords: phosphorus, eutrophication control, bentonite, ion exchange, environmental remediation

\section{Introduction}

Phosphorus is an essential macronutrient for the maintenance of life and growth of several organisms. It constitutes the ADP/ATP (adenosine di-phosphate/ adenosine tri-phosphate) molecules and takes parts in the chemical bonds in DNA/RNA (deoxyribonucleic acid/ ribonucleic acid). ${ }^{1}$ In natural waters, phosphorus is found in the form of particulate phosphate, organic phosphate, dissolved inorganic phosphate, and total phosphorus. In this study, dissolved inorganic phosphate, also known as orthophosphate or soluble reactive phosphate (SRP), was our target. SRP represents a fraction of low concentration within the biogeochemical cycle of phosphorus when

*e-mail: vgomes@iq.ufrj.br compared to the other forms of phosphorus, but it is the only form of assimilation by primary producers. ${ }^{2}$ The substantial contribution of this nutrient, considered a limiting nutrient for plant growth, together with nitrogen, enables the eutrophication process of aquatic ecosystems. Many sources, such as untreated domestic/industrial wastewater and the use of fertilizers in large quantities, have been reported as the main causes of eutrophication in freshwater bodies and rivers, ${ }^{3}$ such as the Jacarepaguá Lagoon. This environment, located on the south coast of Rio de Janeiro State, in the metropolitan region of the city of Rio de Janeiro, Brazil, receives a large number of different types of effluents, such as domestic sewage from nearby urban areas. These effluents contribute to the contamination of water by different pollutants and, thus, to eutrophication. ${ }^{4-9}$ 
Various technologies for the removal of phosphate from water and wastewater have been studied. These include biological treatment, chemical precipitation, crystallization, ion exchange, and adsorption. ${ }^{10-12}$ The adsorption process is widely recommended for environments with low concentrations of phosphorus. Studies on the treatment of eutrophic aquatic environments by adsorption with aluminum and iron compounds (such as sulfates, hydroxides, or supported on other materials) have been conducted for many years. ${ }^{13-17}$ However, studies have evaluated that $\mathrm{pH}$ conditions outside of neutrality $(\mathrm{pH}$ 6.5-7.0) may increase the bioavailability of aluminum in its forms toxic to aquatic organisms. ${ }^{18-21}$ On the other hand, iron can suffer the effect of the redox potential in aquatic environments. Further, clay mineral montmorillonites are among the adsorbents that have been investigated for the elimination of contaminants. ${ }^{22,23}$ Lanthanum-modified clays have been evaluated as promising agents for phosphate adsorption from surface waters by the Commonwealth Scientific and Industrial Research Organization (CISRO). This has been mainly since the development in the 1990s of a product called Phoslock $^{\circledR}$, a bentonite modified with lanthanum. ${ }^{24-29}$ The presence of lanthanum in the clays is a proposal for remediation of the low stability of aluminum and iron in such aquatic systems. In the case of phosphorus adsorption by lanthanum-modified clays, the formation of the rhabdophane $\left(\mathrm{La}_{3} \mathrm{PO}_{4}\right)$ hinders the release of lanthanum(III) and makes this modified material suitable for application in aquatic environments. ${ }^{29}$ After phosphate chemisorption occurs in the lanthanum-modified clay, the material is deposited along with the sediment and does not undergo chemical changes in a wide range of $\mathrm{pH}^{29-32}$

Studies on lanthanum toxicity in aquatic environments have evaluated the safety of its use. Therefore, materials containing lanthanum(III) have been applied in lifecontaining systems. A study by Waajen et al. ${ }^{33}$ evaluated the accumulation of lanthanum in a lake over a period of five years after application of lanthanum-modified material. Macrophytes, chyromyids, and fish were evaluated, with the highest concentrations of lanthanum found in fish liver, thereby indicating bioaccumulation. However, no ecotoxicological effects were observed during the periods. Balusamy et al. ${ }^{34}$ evaluated the presence of $\mathrm{La}_{2} \mathrm{O}_{3}$ nanoparticles in fresh water, and they found that it did not affect the microalgae Chlorella sp. until a dose of $1000 \mathrm{mg} \mathrm{L}^{-1}$ of nanoparticles was administered. For the crustacean Daphnia magna, their tests determined $250 \mathrm{mg} \mathrm{L}^{-1}$ to be the maximum safe dose. The authors believe that long-term studies are required to ensure the safety of aquatic organisms and human health. Further, they also investigated the role of lanthanum in phosphate removal as well as its antibacterial effect through the use of $\mathrm{La}(\mathrm{OH})_{3}$ nanoblasts dispersed in polyacrylonitrile nanofibers. The results were promising and demonstrated a phosphate capture capacity that was approximately eight times higher than that of the $\mathrm{La}(\mathrm{OH})_{3}$ nanocrystal. ${ }^{35}$

Considering these advantages of the use of lanthanummodified montmorillonite for phosphate adsorption, this work intends to evaluate certain aspects that have not been answered by the scientific community, such as the influence of the type of montmorillonite/bentonite used as the precursor of the adsorbent; the influence of the increase in the amount of lanthanum incorporated in the adsorption capacity of the material; and the substitution of a proportion of the lanthanum by iron, since this modification can impart some economic advantage to the adsorbent.

Thus, we conducted a study on the correlation of the kinetic and equilibrium phosphate adsorption of two clays with their chemical and textural properties. In addition, we evaluated the prepared materials in a laboratory test using natural water from the Jacarepaguá Lagoon. Therefore, we hope to contribute to the research and development of a national product with good performance for the remediation of eutrophic aquatic environments.

\section{Experimental}

\section{Materials}

The reagents used were potassium dihydrogen phosphate $\left(\mathrm{KH}_{2} \mathrm{PO}_{4}\right)$ for analysis ISO (Merck), ferric nitrate nonahydrate $\left(\mathrm{Fe}\left(\mathrm{NO}_{3}\right)_{3} \cdot 9 \mathrm{H}_{2} \mathrm{O}\right)$ for analysis ACS (SigmaAldrich-Vetec), lanthanum oxide $\left(\mathrm{La}_{2} \mathrm{O}_{3}\right) 99.98 \%$ (Fluka), ascorbic acid $\mathrm{PA}\left(\mathrm{C}_{6} \mathrm{H}_{8} \mathrm{O}_{6}\right)$ (Sigma-Aldrich), nitric acid PA $\left(\mathrm{HNO}_{3}\right) 65 \%$ for analysis ISO (Merck), sulfuric acid PA $\left(\mathrm{H}_{2} \mathrm{SO}_{4}\right)$ 95-97\% for analysis ISO (Merck), ammonium heptamolybdate tetrahydrate for analysis (Merck), antimony and potassium tartrate for analysis (SigmaAldrich), methylene blue for microscopy (Merck), sodium hexametaphosphate (Sigma-Aldrich), ethylene glycol (Sigma-Aldrich), $1000 \mathrm{mg} \mathrm{L}^{-1}$ phosphate standard solution in water (SpecSol), $1000 \mathrm{mg} \mathrm{L}^{-1}$ chloride standard solution in water (SpecSol), $1000 \mathrm{mg} \mathrm{L}^{-1}$ nitrate standard solution in water (SpecSol), $1000 \mathrm{mg} \mathrm{L}^{-1}$ sulfate standard solution in water (SpecSol), buffer solutions pH 4 and 7 (Inmetro, MRC 8832.0004 and MRC 8855.0003), electrolytic conductivity solution $1400 \mu \mathrm{S} \mathrm{cm}^{-1}$ (Inmetro, MRC 8844.0003). The filters used were Whatman $47 \mathrm{~mm} \mathrm{GF/F}, 0.7 \mu \mathrm{m}$ and syringe filter $0.45 \mu \mathrm{m}$ (pre-cleaned, welded, hydrophilic polyvinylidene fluoride (PVDF) membrane, $13 \mathrm{~mm}$ ). All solutions were prepared using deionized water from Milli-Q-Millipore ${ }^{\mathrm{TM}}$, conductivity of $\leq 0.055 \mu \mathrm{S} \mathrm{cm} \mathrm{cm}^{-1}$. 
Two precursor clays were used in this study. The clay referred to as Bent in this study was purchased from Sigma-Aldrich (product name: bentonite-montmorillonite, number: 285234, lot No. MKBP7624V, CAS number: 1302-78-9, formula: $\mathrm{H}_{2} \mathrm{Al}_{2} \mathrm{O}_{6} \mathrm{Si}_{-} \mathrm{Al}_{2} \mathrm{O}_{3} .4 \mathrm{SiO}_{2} \cdot \mathrm{H}_{2} \mathrm{O}$, formula weight: $180.1 \mathrm{~g} \mathrm{~mol}^{-1}$, loss on drying: $\left.6.5 \%, \mathrm{pH}: 10.2\right)$. The other clay, referred to as PetBent in this study, was a pet litter line commercially named Peepcat, manufactured by Bentonite União Nordeste Ind. and Com. Ltda (Boa VistaPB, Brazil) and distributed by Kelco Pet Care Produtos para Animais Ltda (São Paulo-SP, Brazil), composition: clay smectite, lot B100314/7E2336.

\section{Preparation of adsorbent materials}

The clay minerals were modified by the ion exchange procedure in aqueous solutions containing the cations of interest. Lanthanum and iron solutions were prepared from lanthanum(III) oxide and iron(III) nitrate in 5\% $(\mathrm{v} / \mathrm{v}) \mathrm{HNO}_{3}$. In order to prepare the modified materials, lanthanum(III) solutions were used in the following concentrations: $0.05 \mathrm{~mol} \mathrm{~L}^{-1}$ (La1Bent) and $0.4 \mathrm{~mol} \mathrm{~L}^{-1}$ (La2Bent and La2PetBent). For the material modified with lanthanum(III) and iron(III) (LaFeBent), a solution of $0.2 \mathrm{~mol} \mathrm{~L}^{-1}$ lanthanum(III) and $0.1 \mathrm{~mol} \mathrm{~L}^{-1}$ iron(III) was prepared. The clay and solution were mixed in the mass/ volume ratio of 1:10 (clay:solution) for the modification process. The mixture was magnetically stirred for $24 \mathrm{~h}$ at room temperature $(298 \mathrm{~K}) .^{28,36}$ Thereafter, the material was filtered, washed with deionized water, and dried at $378 \mathrm{~K}$. Before and after the process of modification, the granulometry was adjusted with a 100 mesh sieve (internal aperture equal to $0.149 \mathrm{~mm}$ ).

\section{X-ray fluorescence spectroscopy with wavelength dispersion (WD-XRF)}

The chemical composition of the materials was determined by WD-XRF in a S8-TIGER Bruker spectrometer. For the analysis, the samples in the powder form were pressed in the form of pellets, using boric acid as support.

\section{Textural analysis}

The textural analysis was conducted using the automatic equipment ASAP 2420 Micromeritics. The pretreatment of the samples consisted of drying $300 \mathrm{mg}$ at $473 \mathrm{~K}$ for $12 \mathrm{~h}$ in a laboratory electric stove and degassing at $473 \mathrm{~K}$ during $12 \mathrm{~h}(3 \mu \mathrm{mHg})$. The measurement was done by the adsorption-desorption of $\mathrm{N}_{2}$ at its boiling temperature of
$77 \mathrm{~K}$. The specific area was calculated by the BrunauerEmmett-Teller (BET) method and the pore diameter and pore volume were calculated by the Barrett-Joyner-Halenda (BJH) method.

\section{Cation exchange capacity (CEC)}

The CEC was quantified by the methylene blue test. ${ }^{37}$

\section{X-ray diffraction $(\mathrm{XRD})$}

In order to confirm the identity of the montmorillonites, the X-ray diffractograms (XRD) of the Bent and PetBent samples (natural, calcined, and glycolated) were achieved..$^{38}$ Initially, the concentration of the clay fraction was determined by weighing $1.5 \mathrm{~g}$ of the dry clay into the beaker and adding $50 \mathrm{~mL}$ of distilled water. Two drops of a preprepared solution of $0.5 \%(\mathrm{~m} / \mathrm{v})$ sodium hexametaphosphate were subsequently added. The suspension was shaken by ultrasound for $1 \mathrm{~min}$, and was then held for $20 \mathrm{~min}$. Thereafter, with the aid of a pipette, the fine fraction was carefully removed, avoiding disturbance to the medium. After this procedure, the content left in the beaker was left to stand for $48 \mathrm{~h}$. Then, the liquid was pipetted out to fill three glass slides. These slides were oven-dried at $333 \mathrm{~K}$ until completely dried. The first (natural) slide was considered ready for analysis after the drying procedure. The second (calcined) slide was fed into a furnace at $773 \mathrm{~K}$, and the third slide (glycolated) was submitted to an ethylene glycol atmosphere for $4 \mathrm{~h}$ in a vacuum desiccator containing the liquid at the bottom of the vessel.

The glass slides with the natural, calcined, and glycolated samples were analyzed in a diffractometer D8 Advance Eco Bruker-AXS CuK $\alpha(\lambda=0.154056 \mathrm{~nm})$; the generator operated at $40 \mathrm{kV}$ and $25 \mathrm{~mA}$, goniometer velocity of $2 \theta=0.02^{\circ}$ per step with a counting time of $1 \mathrm{~s}$ per step and collected $2 \theta=2$ to $40^{\circ}$, position-sensitive detector with energy discrimination LynxEye XE. Qualitative interpretations of spectrum were performed by comparison with standards contained in the PDF02 database (ICDD, 2006) of the Bruker AXS Diffrac.Plus software. The interlayer distances (d) were calculated according to Bragg's law, $\mathrm{n} \lambda=2 \mathrm{~d} \operatorname{sen} \theta$, where $\mathrm{n}$ is an integer multiple of the wavelength, $\lambda$ is the wavelength of the incident $\mathrm{X}$-ray beam, and $2 \theta$ is the diffraction angle.

The XRD evaluation of the lanthanum/iron-modified materials was conducted in an Ultima IV Rigaku diffractometer, frequency radiation of $3 \mathrm{~kW} \mathrm{CuK \alpha}$ $(\lambda=0.15418 \mathrm{~nm})$, and normal focus of $2 \mathrm{~kW}$; the data acquisition was made at an interval of $0.05^{\circ}$ between $2 \theta=5^{\circ}$ to $80^{\circ}$. 
Scanning electron microscopy with energy dispersive spectroscopy (SEM/EDS)

All clays were characterized by scanning electron microscopy (SEM) in a Hitachi TM3000 with energy dispersive spectroscopy (EDS) Bruker Quantax 70, silicon drift detector (SDD) and energy $154 \mathrm{eV}(\mathrm{CuK} \alpha)$ equivalent to $137 \mathrm{eV}$ with $\mathrm{MnK} \alpha$. The samples were dispersed in a $12 \mathrm{~mm}$ carbon conductive tape prior to the analysis.

\section{Fourier transform infrared spectroscopy (FTIR)}

FTIR spectra in the wave number range of 4000 to $400 \mathrm{~cm}^{-1}$ were recorded on a 6700 FT-IR Nicolet spectrometer, with the samples dispersed in $\mathrm{KBr}$ disks in a spectral resolution of $4 \mathrm{~cm}^{-1}$.

\section{Study of the effect of $\mathrm{pH}$ on phosphate adsorption}

The experiments designed to evaluate the effect of $\mathrm{pH}$ on the inorganic phosphate adsorption process were conducted in a batch using a shaker table at $150 \mathrm{rpm}, 50 \mathrm{~mL}$ tubes, and fixed adsorbent mass of $0.15 \mathrm{~g}$. The phosphate stock solution of $100 \mathrm{mg} \mathrm{L}^{-1}$ was prepared by dissolving potassium dihydrogen phosphate $\left(\mathrm{KH}_{2} \mathrm{PO}_{4}\right)$ in deionized water. The initial $\mathrm{pH}$ of the solutions was adjusted to 4.0, 6.0, 8.0, and 10.0, with $0.5 \mathrm{~mol} \mathrm{~L}^{-1} \mathrm{HCl}$ and/or $0.5 \mathrm{~mol} \mathrm{~L}^{-1}$ $\mathrm{NaOH}$ solutions. After the adsorption period, the suspension was filtered using $0.45 \mu \mathrm{m}$ hydrophilic PVDF-membrane syringe filter for the analysis of phosphate concentration in the solution.

\section{Kinetic study of phosphate adsorption}

Adsorption experiments for the kinetic study were conducted in the following manner: $0.15 \mathrm{~g}$ of each adsorbent was suspended in $50 \mathrm{~mL}$ of solution containing $50 \mathrm{mg} \mathrm{L}^{-1}$ of phosphate prepared by dissolving $\mathrm{KH}_{2} \mathrm{PO}_{4}$ in deionized water. The initial $\mathrm{pH}$ of the solution was adjusted to 6.0 with $0.5 \mathrm{~mol} \mathrm{~L}^{-1} \mathrm{HCl}$ and/or $0.5 \mathrm{~mol} \mathrm{~L}^{-1} \mathrm{NaOH}$ solutions. The tests were conducted at the temperature of $296 \pm 2 \mathrm{~K}$ under constant stirring at $150 \mathrm{rpm}$. During the batch test, aliquots from the solution were withdrawn at time intervals of $1,3,6,12,24,48,72$, and $96 \mathrm{~h}$ for analysis of the residual phosphate concentration. The suspension was filtered using $0.45 \mu \mathrm{m}$ hydrophilic PVDF-membrane syringe filter for the determination of phosphate concentration. All experiments were conducted in duplicate, and the mean of the determined values was calculated. The batches were conducted in duplicate, with blank (tubes containing only the stock solution, without adsorbent) and control (tubes with stock solutions and the adsorbent, without chemical modification) experiments running in parallel.

The kinetic models of pseudo-first order and pseudosecond order are usually well-suited for describing the kinetic parameters of adsorption processes that occur at the interface of the solid adsorbent and solution. ${ }^{36,39}$ In addition, the intraparticle diffusion model can also describe the adsorption processes. ${ }^{39,40}$

The kinetic models of pseudo-first order, pseudo-second order, and intra-particle diffusion in their linear forms were evaluated according to equations 1,2 , and 3 , respectively: ${ }^{41-44}$

$$
\begin{aligned}
& \log \left(\mathrm{q}_{\mathrm{e}}-\mathrm{q}_{\mathrm{t}}\right)=\log \mathrm{q}_{\mathrm{e}}-\frac{\mathrm{k}_{1}}{2.303} \mathrm{t} \\
& \frac{\mathrm{t}}{\mathrm{q}_{\mathrm{t}}}=\frac{1}{\mathrm{k}_{2} \mathrm{q}_{\mathrm{e}}^{2}}+\left(\frac{1}{\mathrm{q}_{\mathrm{e}}}\right) \mathrm{t}
\end{aligned}
$$

$\mathrm{q}_{\mathrm{t}}=\mathrm{C}+\mathrm{k}_{\text {int }} \mathrm{t}^{\frac{1}{2}}$

where $\mathrm{q}_{\mathrm{e}}$ and $\mathrm{q}_{\mathrm{t}}$ are the amounts of phosphate adsorbed at the equilibrium and at any time $\mathrm{t}$, respectively $\left(\mathrm{mg} \mathrm{g}^{-1}\right)$; $\mathrm{k}_{1}$ is the rate constant of pseudo-first order adsorption, $\mathrm{k}_{2}$ is the pseudo-second order rate constant; $\mathrm{C}\left(\mathrm{mg} \mathrm{g}^{-1}\right)$ is the intercept, a constant related to the thickness of the boundary layer; and $\mathrm{k}_{\mathrm{int}}$ is the rate of intra-particle diffusion.

The adsorption rate, $\mathrm{h}\left(\mathrm{mg} \mathrm{g}^{-1} \mathrm{~h}^{-1}\right)$, can be calculated ${ }^{44}$ using the following equation:

$\mathrm{h}=\frac{\mathrm{q}_{\mathrm{t}}}{\mathrm{t}}=\mathrm{k}_{2} \mathrm{q}_{\mathrm{e}}^{2}$

Phosphate adsorption studies

The experiments for the adsorption equilibrium study were conducted in a batch shaker using $50 \mathrm{~mL}$ tubes and a fixed adsorbent mass of $0.25 \mathrm{~g}$. The initial concentrations of the phosphate stock solutions were measured, as described in the next item, and the following values were determined: $0.49 ; 4.98 ; 15.03 ; 51.27 ; 100.60 ; 211.98 ; 519.28 ; 1006.87$; 2026.58; 3025.08; $4032.25 \mathrm{mg} \mathrm{L}^{-1}$. All these solutions were prepared by dissolving $\mathrm{KH}_{2} \mathrm{PO}_{4}$ in deionized water. The initial $\mathrm{pH}$ of the solutions was adjusted to 6.0, with $0.5 \mathrm{~mol} \mathrm{~L}^{-1} \mathrm{HCl}$ and/or $0.5 \mathrm{~mol} \mathrm{~L}^{-1} \mathrm{NaOH}$ solutions. The tests were conducted at a temperature of $296 \pm 2 \mathrm{~K}$ for $96 \mathrm{~h}$, in a shaker table with horizontal oscillation at the speed of $150 \mathrm{rpm}$. The batches were conducted in duplicate, with blank and control experiments running in parallel as previously described. After the adsorption period, the suspension was filtered using $0.45 \mu \mathrm{m}$ hydrophilic PVDF-membrane syringe filter for the analysis of phosphate concentration in the solution. 
The amount of phosphate adsorbed per gram of clay at the equilibrium $\left(\mathrm{q}_{\mathrm{e}}, \mathrm{mg} \mathrm{g}^{-1}\right)$ was calculated using the following equation:

$\mathrm{q}_{\mathrm{e}}=\frac{\left(\mathrm{C}_{0}-\mathrm{C}_{\mathrm{e}}\right)}{\mathrm{m}} \mathrm{V}$

where $\mathrm{C}_{0}$ is the initial phosphate concentration $\left(\mathrm{mg} \mathrm{L}^{-1}\right)$, $\mathrm{C}_{\mathrm{e}}$ is the equilibrium phosphate concentration $\left(\mathrm{mg} \mathrm{L}^{-1}\right), \mathrm{V}$ is the volume (L) of the phosphate solution, and $\mathrm{m}$ is the mass (g) of the adsorbent used.

The experimental data were tested and compared with two isotherm models, Langmuir and Freundlich. ${ }^{36,39}$ The linearized Langmuir isotherm model is described by the following equation:

$\frac{\mathrm{C}_{\mathrm{e}}}{\mathrm{q}_{\mathrm{e}}}=\frac{1}{\mathrm{~K}_{\mathrm{L}} \mathrm{Q}_{\max }}+\left(\frac{1}{\mathrm{Q}_{\max }}\right) \mathrm{C}_{\mathrm{e}}$

where $\mathrm{Q}_{\max }$ is the maximum adsorption capacity $\left(\mathrm{mg} \mathrm{g}^{-1}\right)$, and $\mathrm{K}_{\mathrm{L}}$ is the Langmuir equilibrium constant $\left(\mathrm{L} \mathrm{mg}^{-1}\right)$.

The equilibrium parameter, $\mathrm{R}_{\mathrm{L}}$ (dimensionless), can be calculated according to the following equation:

$\mathrm{R}_{\mathrm{L}}=\frac{1}{1+\mathrm{K}_{\mathrm{L}} \mathrm{C}_{0}}$

where $\mathrm{C}_{0}\left(\mathrm{mg} \mathrm{L}^{-1}\right)$ is the initial phosphate concentration in the solution with the highest concentration. The reversibility of the process can be evaluated by the $R_{L}$ parameter considering the following criteria: if $R_{L}=0$, the process is irreversible; for $0<\mathrm{R}_{\mathrm{L}}<1$, it is favorable and for $R_{L}>1$, it is not favorable.

The Freundlich isotherm is given by the following equation:

$\mathrm{q}_{\mathrm{e}}=\mathrm{K}_{\mathrm{F}} \mathrm{C}_{\mathrm{e}}^{1 / \mathrm{n}}$

where $\mathrm{K}_{\mathrm{F}}$ is the Freundlich constant $\left[\mathrm{mg} \mathrm{g}^{-1} /\left(\mathrm{mg} \mathrm{L}^{-1}\right)^{1 / n}\right]$, and $\mathrm{n}$ is the Freundlich intensity parameter (dimensionless).

Further, the linearized Freundlich equation is represented as

$\log \mathrm{q}_{\mathrm{e}}=\log \mathrm{K}_{\mathrm{F}}+\frac{1}{\mathrm{n}} \log \mathrm{C}_{\mathrm{e}}$

Analysis of phosphate, chloride, nitrate, and sulfate anions

The quantification of the inorganic phosphate in water was conducted by the molybdenum-blue/ascorbic acid spectrophotometric method at $880 \mathrm{~nm}^{45}$ in a Lambda 45 PerkinElmer UV-Vis spectrophotometer. A $1000 \mathrm{mg} \mathrm{L}^{-1}$ standard solution of phosphate in water was used for the construction of the analytical curve.

For the determination of the chloride $\left(\mathrm{Cl}^{-}\right)$, nitrate $\left(\mathrm{NO}_{3}{ }^{-}\right)$, and sulfate $\left(\mathrm{SO}_{4}{ }^{2-}\right)$ anions, the Metrohm 850 ion chromatography system was used. For the construction of the analytical curve, $1000 \mathrm{mg} \mathrm{L}^{-1}$ standard solutions of anions in water were used. The analytical characteristics employed were: conductivity detector; eluent composition: $3.2 \mathrm{mmol} \mathrm{L}^{-1} \mathrm{Na}_{2} \mathrm{CO}_{3} / 1.0 \mathrm{mmol} \mathrm{L}{ }^{-1} \mathrm{NaHCO}_{3}$; flow: $0.7 \mathrm{~mL} \mathrm{~min}^{-1}$; column: Metrosep A Supp 5 250/4.0 mm (polyvinyl alcohol with quarternary ammonium); pressure: $12.67 \mathrm{MPa}$; and loop: $100 \mu \mathrm{L}$.

Sampling and analysis of the water from the Jacarepaguá Lagoon (Rio de Janeiro, Brazil)

The water sample was collected on December 2017, from the Jacarepaguá Lagoon, in the Olympic Park at Barra in the state of Rio de Janeiro, Brazil. The location latitude is $22^{\circ} 59^{\prime} 1.56^{\prime \prime} \mathrm{S}$ and longitude $43^{\circ} 23^{\prime} 35.49^{\prime} \mathrm{W}^{46,47}$

The water sample showed a cloudy visual appearance and green coloration. The following parameters were controlled: temperature and $\mathrm{pH}$ (YSI pH 100); conductivity and salinity (YSI Model 30 salinity, conductivity, and temperature handheld instrument); dissolved oxygen (YSI Model 55 dissolved oxygen and temperature handheld instrument).

The suspended particulate matter (SPM) was determined in the laboratory by filtration of $200 \mathrm{~mL}$ of the water sample through a glass fiber filter (Whatman $47 \mathrm{~mm} \mathrm{GF} / \mathrm{F}, 0.7 \mu \mathrm{m}$ ). The SPM was determined by the difference in the mass of the filter after the filtering process and in the dry state, divided by the volume of the filtered sample. The filter was dried in an oven at $353 \mathrm{~K}$ in both processes, being carried to constant weight. The determination of SPM $\left(\mathrm{mg} \mathrm{L}^{-1}\right)$ was performed in duplicate.

The determination of the total phosphorus was performed without sample filtration, through the acid digestion procedure, followed by its quantification by the colorimetric method with ascorbic acid (4500-P E). ${ }^{45}$ The soluble reactive phosphate was determined by the filtration of the sample in a $0.45 \mu \mathrm{m}$ membrane filter, without an acid digestion procedure, followed by colorimetric determination by the ascorbic acid method (4500-P E). ${ }^{45}$

Laboratory adsorption test on the real sample from the Jacarepaguá Lagoon (Rio de Janeiro, Brazil)

The adsorption experiments using the real water sample were conducted in the laboratory in a controlled temperature environment at $298 \pm 2 \mathrm{~K}$. Batch tests were conducted using 
$50 \mathrm{~mL}$ tubes, with a mass of $0.005 \mathrm{~g}$ of the adsorbent in a stirrer table at $150 \mathrm{rpm}$. The batches were conducted in duplicate, with blank and control experiments running in parallel. The experiment was performed during $72 \mathrm{~h}$. Aliquots were taken from the solution after 0.5, 1, 3, 6, 9, 12,24 , and $48 \mathrm{~h}$ of contact. After each adsorption period, the suspension was filtered using a $0.45 \mu \mathrm{m}$ hydrophilic PVDFmembrane syringe filter to determine the concentration of phosphate. The $\mathrm{pH}$ values were monitored every $24 \mathrm{~h}$ throughout the experiment.

\section{Results and Discussion}

Considering our interest in evaluating a Brazilian commercial clay as a promising phosphate adsorbent in eutrophic aquatic environments, we decided to compare this material with a reference bentonite-montmorillonite from Sigma-Aldrich. Thus, the study was conducted using the commercial clay from Bentonite União Nordeste Ind. and Com. Ltda called PetBent and the reference one from Sigma-Aldrich called Bent.

\section{Preparation and characterizations of the clay minerals}

The diffractograms of the Bent and PetBent precursor clay minerals are depicted in Figures 1 and 2, respectively. The diffraction pattern reveals the greater crystallinity of the Bent sample as compared to the PetBent sample. However, in this study, we sought to identify the PetBent as a montmorillonite. Thus, the glycolation procedure, often used to identify clay minerals, was adopted. In this process, the material in the form of dried glass slides is exposed to vapors of ethylene glycol in a closed vessel, which penetrate into the interlayers and results in its expansion. According

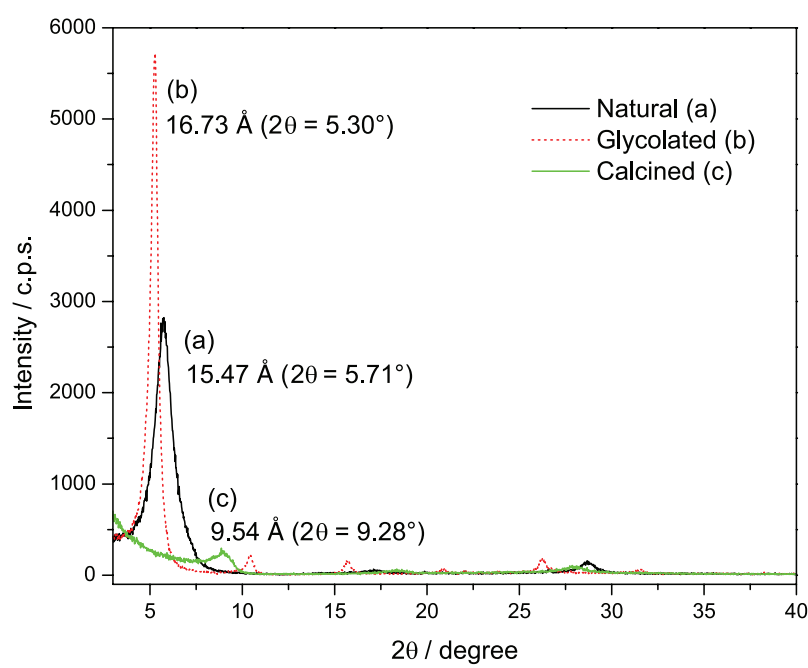

Figure 1. X-ray diffraction patterns of Bent: (a) natural; (b) glycolated; (c) calcined.

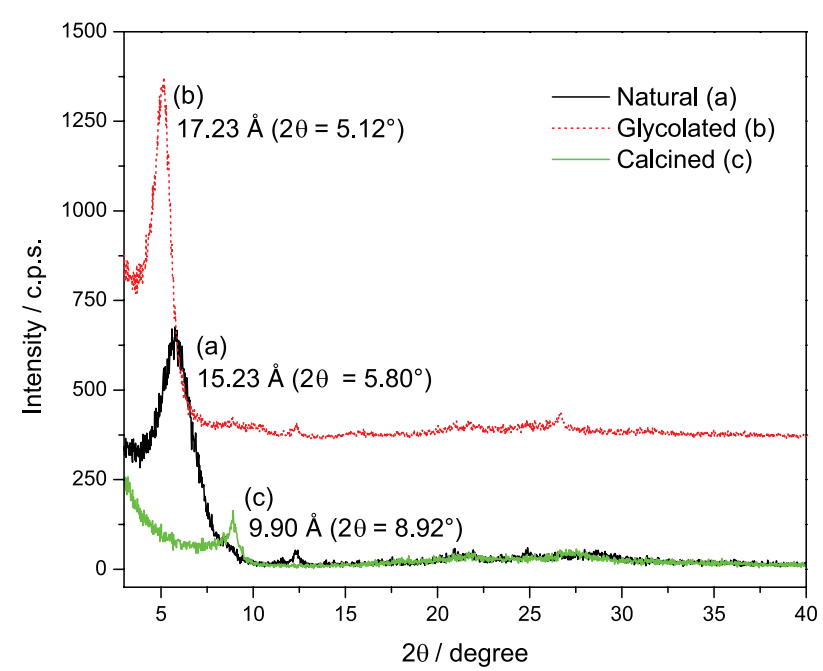

Figure 2. X-ray diffraction patterns of PetBent: (a) natural; (b) glycolated; (c) calcined.

to the data in the literature, ${ }^{38}$ the expected values for the interlayer distance of montmorillonites are 12 to $15 \AA$ for the natural, $10 \AA$ for the calcined, and 16 to $18 \AA$ for the glycolated clay.

The analysis of the clay in the natural form (Figures 1a and 2a) and submitted to the procedures of glycolation (Figures $1 \mathrm{~b}$ and $2 \mathrm{~b}$ ) and calcination (Figures $1 \mathrm{c}$ and 2c) enabled the identification of the mineral as a montmorillonite. A typical basal reflection peak (001) with interlayer distance of $15.47 \AA\left(2 \theta=5.71^{\circ}\right)$ for Bent and $15.23 \AA\left(2 \theta=5.80^{\circ}\right)$ for PetBent was also observed. By means of the glycolation procedure, the interlayer expansion process was forced, as can be observed by the results obtained: $16.73 \AA\left(2 \theta=5.30^{\circ}\right)$ for Bent and $17.23 \AA$ $\left(2 \theta=5.12^{\circ}\right)$ for PetBent. On the other hand, the expulsion of the water molecules occurred during the calcinations and led to the reduction of the interlayer distance, as described by the new values of $9.54 \AA\left(2 \theta=9.28^{\circ}\right)$ for Bent and $9.90 \AA$ $\left(2 \theta=8.92^{\circ}\right)$ for PetBent. These interlayer distances and peak displacement are in agreement with those reported in the literature for montmorillonite. ${ }^{28,38}$

After the characterization of PetBent as a montmorillonite, both materials were modified with lanthanum(III) and iron(III). The X-ray diffractograms of the precursor and modified clay minerals are depicted in Figure 3. A comparison of the diffractograms of the unmodified precursor clays, Bent (Figure 3a) and PetBent (Figure 3e), reveals that they have the same pattern. However, peaks with higher intensity at $20^{\circ}$ and $62^{\circ}$, a characteristic of montmorillonite, are observed for the reference clay. This is due to what probably results from the beneficiation and purification processes, such as sieve fractionation in which a large amount of the impurities, such as quartz, feldspar, carbonates and organic matter, are eliminated. ${ }^{48-50}$ 


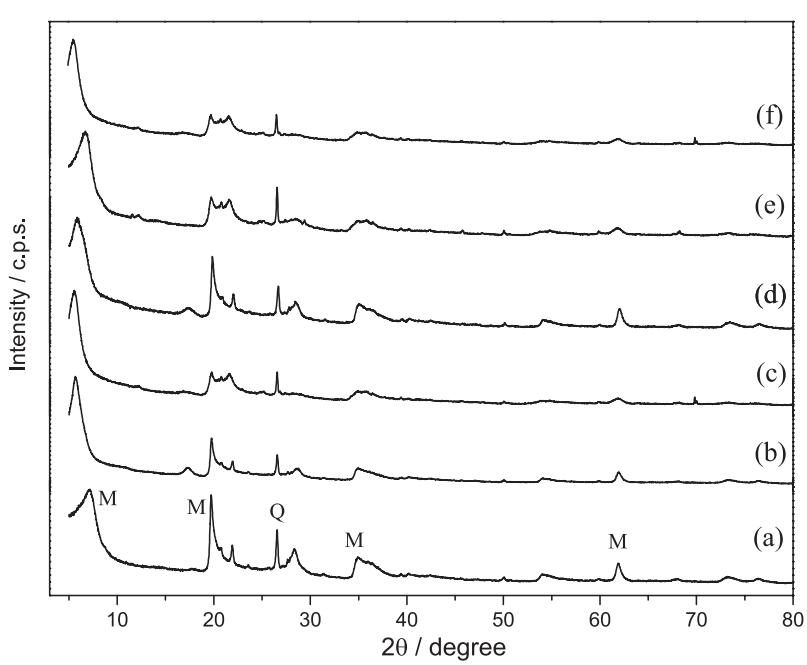

Figure 3. X-ray diffraction patterns of (a) Bent; (b) La1Bent; (c) La2Bent; (d) LaFeBent; (e) PetBent; (f) La2PetBent. M: montmorillonite, Q: quartz.

PetBent also shows a typical behavior of montmorillonites, with a (001) reflection (basal reflection). A characteristic peak at $2 \theta=7^{\circ}$ also infers the possibility of being a montmorillonite. In addition, the presence of quartz was identified by the peak at $26.5^{\circ}$. The diffractograms acquired before and after the ion exchange with lanthanum(III) and iron(III) cations reveal that the chemically modified clays are similar to unmodified ones
(Bent and PetBent), thereby indicating little change in crystalline phases with the ion exchange process.

The results of the chemical composition obtained by WD-XRF and the cation exchange capacity are reported in Table 1. As is evident, the two precursor montmorillonites clay minerals (without modification), Bent and PetBent, have different percentages of $\mathrm{Fe}_{2} \mathrm{O}_{3}$, $3.88 \pm 0.01$ and $8.06 \pm 0.02 \%$, respectively. As expected, La2Bent is the modified clay obtained with the higher $\mathrm{La}_{2} \mathrm{O}_{3}$ content $4.00 \pm 0.03 \%$, since it was modified with the more concentrated lanthanum(III) solution $\left(0.4 \mathrm{~mol} \mathrm{~L}^{-1}\right)$. However, the La2PetBent clay did not attain the same degree of incorporation of lanthanum(III). Even though it was modified with the same solution, it was only $2.65 \pm 0.03 \%$ in $\mathrm{La}_{2} \mathrm{O}_{3}$.

The clay modified with the solution containing iron(III) and lanthanum(III) (LaFeBent) incorporated a small percentage of iron, changing its iron content from $3.88 \pm 0.01$ to $4.69 \pm 0.04 \%$; its La content was $2.17 \pm 0.06 \%$.

Although the chemical composition was transformed, there were no differences in the X-ray diffraction pattern illustrated in Figure 3, which indicates that there was no change in the crystal structure. Further, it can be concluded that there was no deposition of lanthanum or iron oxide on

Table 1. Chemical composition, CEC, and textural properties of clay minerals

\begin{tabular}{|c|c|c|c|c|c|c|c|}
\hline & & Bent & La1Bent & La2Bent & LaFeBent & PetBent & La2PetBent \\
\hline \multirow{2}{*}{ Modification } & $\mathrm{La}^{3+} /\left(\mathrm{mol} \mathrm{L}^{-1}\right)$ & - & 0.05 & 0.4 & 0.2 & - & 0.4 \\
\hline & $\mathrm{Fe}^{3+} /\left(\mathrm{mol} \mathrm{L}^{-1}\right)$ & - & - & - & 0.1 & - & - \\
\hline \multirow{8}{*}{ Chemical composition / wt. $\%,\left(\mathrm{mg} \mathrm{g}^{-1}\right)$} & $\mathrm{SiO}_{2}$ & $\begin{array}{c}67.0 \pm 0.1 \\
(669.9)\end{array}$ & $\begin{array}{c}67.4 \pm 0.2 \\
(674.0)\end{array}$ & $\begin{array}{c}65.2 \pm 0.1 \\
(651.9)\end{array}$ & $\begin{array}{c}68.2 \pm 0.2 \\
(681.8)\end{array}$ & $\begin{array}{c}68.0 \pm 0.1 \\
(680.3)\end{array}$ & $\begin{array}{c}69.4 \pm 0.1 \\
(694.3)\end{array}$ \\
\hline & $\mathrm{Al}_{2} \mathrm{O}_{3}$ & $\begin{array}{c}22.7 \pm 0.1 \\
(227.5)\end{array}$ & $\begin{array}{c}23.0 \pm 0.2 \\
(229.9)\end{array}$ & $\begin{array}{c}22.9 \pm 0.1 \\
(228.7)\end{array}$ & $\begin{array}{c}21.5 \pm 0.3 \\
(215.2)\end{array}$ & $\begin{array}{c}17.5 \pm 0.2 \\
(175.0)\end{array}$ & $\begin{array}{c}17.6 \pm 0.1 \\
(176.1)\end{array}$ \\
\hline & $\mathrm{Fe}_{2} \mathrm{O}_{3}$ & $\begin{array}{c}3.88 \pm 0.01 \\
\quad(38.8)\end{array}$ & $\begin{array}{c}3.83 \pm 0.01 \\
(38.3)\end{array}$ & $\begin{array}{c}3.71 \pm 0.01 \\
(37.1)\end{array}$ & $\begin{array}{c}4.69 \pm 0.04 \\
(46.9)\end{array}$ & $\begin{array}{c}8.06 \pm 0.02 \\
(80.6)\end{array}$ & $\begin{array}{c}7.66 \pm 0.02 \\
\quad(76.6)\end{array}$ \\
\hline & $\mathrm{La}_{2} \mathrm{O}_{3}$ & 0 & $\begin{array}{c}2.27 \pm 0.02 \\
(22.7)\end{array}$ & $\begin{array}{c}4.00 \pm 0.03 \\
\quad(40.0)\end{array}$ & $\begin{array}{c}2.17 \pm 0.06 \\
(21.7)\end{array}$ & 0 & $\begin{array}{c}2.65 \pm 0.03 \\
(26.5)\end{array}$ \\
\hline & $\mathrm{MgO}$ & $\begin{array}{c}2.62 \pm 0.04 \\
\quad(26.2)\end{array}$ & $\begin{array}{c}2.32 \pm 0.04 \\
(23.2)\end{array}$ & $\begin{array}{c}2.10 \pm 0.04 \\
\quad(21.0)\end{array}$ & $\begin{array}{c}2.29 \pm 0.05 \\
(22.9)\end{array}$ & $\begin{array}{c}2.30 \pm 0.04 \\
(23.0)\end{array}$ & $\begin{array}{c}1.73 \pm 0.04 \\
(17.3)\end{array}$ \\
\hline & $\mathrm{Na}_{2} \mathrm{O}$ & $\begin{array}{c}1.32 \pm 0.05 \\
\quad(13.2)\end{array}$ & $\begin{array}{c}0.28 \pm 0.03 \\
\quad(2.8)\end{array}$ & $\begin{array}{c}0.93 \pm 0.04 \\
(9.3)\end{array}$ & $\begin{array}{c}0.4 \pm 0.1 \\
(3.9)\end{array}$ & $\begin{array}{c}1.10 \pm 0.01 \\
\quad(11.0)\end{array}$ & 0 \\
\hline & $\mathrm{CaO}$ & $\begin{array}{c}1.29 \pm 0.01 \\
(12.9)\end{array}$ & $\begin{array}{c}0.27 \pm 0.01 \\
(2.7)\end{array}$ & $\begin{array}{c}0.65 \pm 0.01 \\
\quad(6.5)\end{array}$ & $\begin{array}{c}0.15 \pm 0.02 \\
\quad(1.5)\end{array}$ & $\begin{array}{c}1.01 \pm 0.01 \\
\quad(10.1)\end{array}$ & 0 \\
\hline & $\mathrm{K}_{2} \mathrm{O}$ & $\begin{array}{c}0.33 \pm 0.01 \\
\quad(3.3)\end{array}$ & $\begin{array}{c}0.30 \pm 0.02 \\
\quad(3.0)\end{array}$ & $\begin{array}{c}0.27 \pm 0.01 \\
\quad(2.7)\end{array}$ & $\begin{array}{c}0.35 \pm 0.01 \\
\quad(3.5)\end{array}$ & $\begin{array}{c}0.75 \pm 0.03 \\
(7.5)\end{array}$ & $\begin{array}{c}0.76 \pm 0.01 \\
(7.6)\end{array}$ \\
\hline $\mathrm{CEC}^{\mathrm{a}} /\left(\mathrm{eq} \mathrm{kg}^{-1}\right)$ & & $0.68 \pm 0.06$ & - & - & - & $0.61 \pm 0.09$ & - \\
\hline Specific surface $\operatorname{area}^{\mathrm{b}} /\left(\mathrm{m}^{2} \mathrm{~g}^{-1}\right)$ & & 31 & 39 & 35 & 40 & 103 & 116 \\
\hline Pore volume $\mathrm{c}^{\mathrm{c}}\left(\mathrm{cm}^{3} \mathrm{~g}^{-1}\right)$ & & 0.10 & 0.11 & 0.09 & 0.09 & 0.14 & 0.16 \\
\hline Desorption average pore diameter ${ }^{c} / \AA$ & & 100 & 74 & 69 & 69 & 60 & 59 \\
\hline
\end{tabular}

${ }^{\mathrm{a} C}$ Cation exchange capacity; ${ }^{\mathrm{b} B r u n a u e r-E m m e t t-T e l l e r ~(B E T) ~ m e t h o d ; ~}{ }^{\mathrm{c}}$ Barrett-Joyner-Halenda (BJH) method. 
the surface of the clay since no peak related to the oxides was revealed in the diffractogram. These results show that the modification with lanthanum(III) and iron(III) must have been conducted by means of the interlayer cations exchange, in this case, $\mathrm{Na}^{+}$and $\mathrm{Ca}^{2+}$. The substitution of these ions can be verified in Table 1 by comparing the concentrations of the interlayer cations in the precursor clay minerals, Bent and PetBent, with those of the modified materials. In addition, the results presented in Figure 3 demonstrate that the ion exchange procedure was effective and that the material purification step did not alter its crystal structure. The results for sodium, calcium, lanthanum, and iron, presented in Table 1, demonstrate that $\mathrm{Na}^{+}$and $\mathrm{Ca}^{2+}$ were changed by $\mathrm{La}^{3+}$ and $\mathrm{Fe}^{3+}$.

The values of cation exchange capacity (CEC) presented in Table 1 for the precursor clay minerals were within the range expected for bentonites/montmorillonites 0.60-0.80 eq $\mathrm{kg}^{-1},{ }^{51-53}$ with 0.68 and $0.61 \mathrm{eq} \mathrm{kg}^{-1}$ for Bent and PetBent, respectively. This characteristic agrees with the percentages of exchangeable cations determined by WD-XRF $\left(\mathrm{Na}_{2} \mathrm{O}\right.$ and $\left.\mathrm{CaO}\right): 2.61 \%$ for Bent and $2.11 \%$ for PetBent. It is evident that PetBent had only a slightly lower CEC and concentration of exchangeable cations than Bent. Considering these results, it is believed that CEC alone did not determine the higher percentage of lanthanum incorporated in La2Bent compared to La2PetBent since this parameter cannot justify the lanthanum incorporation difference of $4.00 \pm 0.03$ and $2.65 \pm 0.03 \%$, respectively. Therefore, other characteristics of the materials, such as their textural properties, must be considered.

Table 1 presents the results of the textural characterization of the clays. Precursor clays Bent and PetBent are different in their textural properties. The Bent clay has the lowest values of area and pore volume, but the largest average diameter of pore. The adsorption/desorption isotherm for both clays (not presented) showed a typical mesoporous pattern of lamellar materials with the formation of hysteresis. For the materials modified using Bent, there was a reduction in the mean pore diameter from $100 \AA$ to the range of 69-74 $\AA$. This reduction can be attributed to the cation exchange in the interlayer structure which, in some manner, can alter the pore size. For the materials modified using PetBent, there was no significant change in the pore volume after the modification process. It is believed that this is due to a smaller extension of cation exchange in this material.

The results expressed herein lead to two hypotheses for the differences in the chemical composition of the two clays after the modification process. The first hypothesis is that the percentage of iron in the sheets influenced the degree of modification. The modified material La2Bent incorporated
$4.00 \pm 0.03 \%$ of $\mathrm{La}_{2} \mathrm{O}_{3}$, while $\mathrm{La} 2 \mathrm{PetBent}$ incorporated only $2.65 \pm 0.03 \%$. The tetrahedral and octahedral sheets of the unmodified PetBent clay contain a higher percentage of iron, $8.06 \pm 0.02 \%$ in $\mathrm{Fe}_{2} \mathrm{O}_{3}$, than that in the Bent clay, $3.88 \pm 0.01 \%$. The higher content of iron(III) in the PetBent sheets (double than in the Bent value) may have prevented a higher percentage of substitution of the exchangeable cations, sodium and calcium, by lanthanum(III) because of the stronger electrostatic effect. ${ }^{54,55}$

The second hypothesis is based on the influence of the pore size on the modification. The larger size of the Bent pores, $100 \AA$, compared to the PetBent pores, $60 \AA$, may have enhanced the diffusion of the lanthanum(III) solution through the inner regions of the more porous material, thereby contributing to the higher efficiency of the ion exchange process.

Further, the infrared spectra of the clays (Figure 4) show the $v \mathrm{O}-\mathrm{H}$ and $v \mathrm{H}-\mathrm{O}-\mathrm{H}$ stretching vibrations in the range of 3635-3640 and $3430 \mathrm{~cm}^{-1}$, asymmetric stretching peaks $v \mathrm{Si}-\mathrm{O}-\mathrm{Si}$ at $1042 \mathrm{~cm}^{-1}$, deformation of $\delta \mathrm{Al}-\mathrm{OH}-\mathrm{Al}(\mathrm{OH})$ at $920 \mathrm{~cm}^{-1}, \mathrm{SiO}_{2}$ (quartz) vibrations at $798 \mathrm{~cm}^{-1}$, and $\checkmark \mathrm{Si}-\mathrm{O}$ and $\mathrm{Al}-\mathrm{O}$ at 524 and $470 \mathrm{~cm}^{-1}$, respectively. ${ }^{56}$ Spectrum changes appear for the modified clay with the highest concentration of lanthanum(III) (La2Bent) in the region of $1383-1494 \mathrm{~cm}^{-1}$. In accordance with the X-ray diffractograms, the infrared spectra also suggest that the ion exchange procedure did not promote modifications in the crystalline structure of the modified clays since no band can be attributed to the stretching of metal-oxygen bounds present in the structure of the tetrahedral and octahedral sheets of montmorillonite.

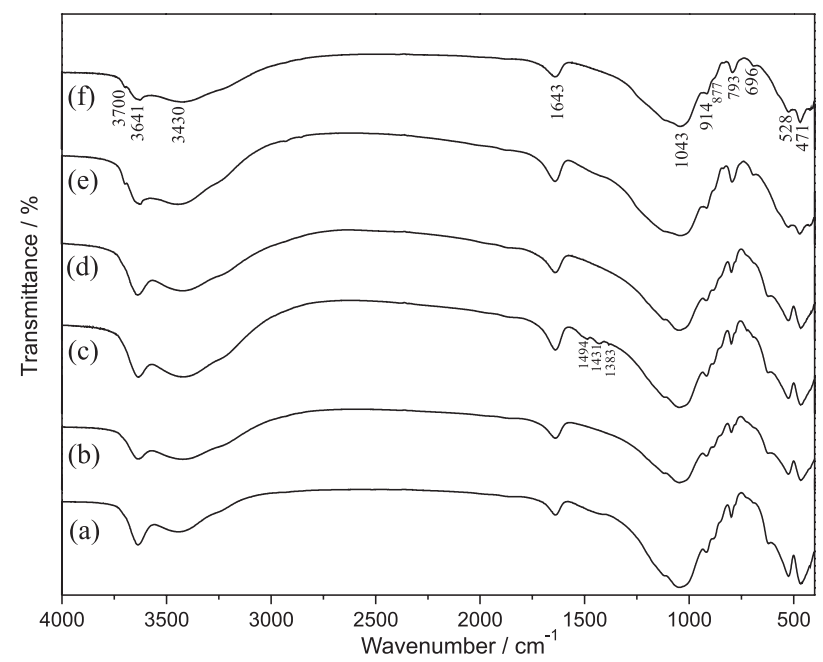

Figure 4. FTIR spectra of (a) Bent; (b) La1Bent; (c) La2Bent; (d) LaFeBent; (e) PetBent; (f) La2PetBent.

The images obtained by SEM (Figure 5) show that, even after the adjustment of granulometry in a 100-mesh sieve, 

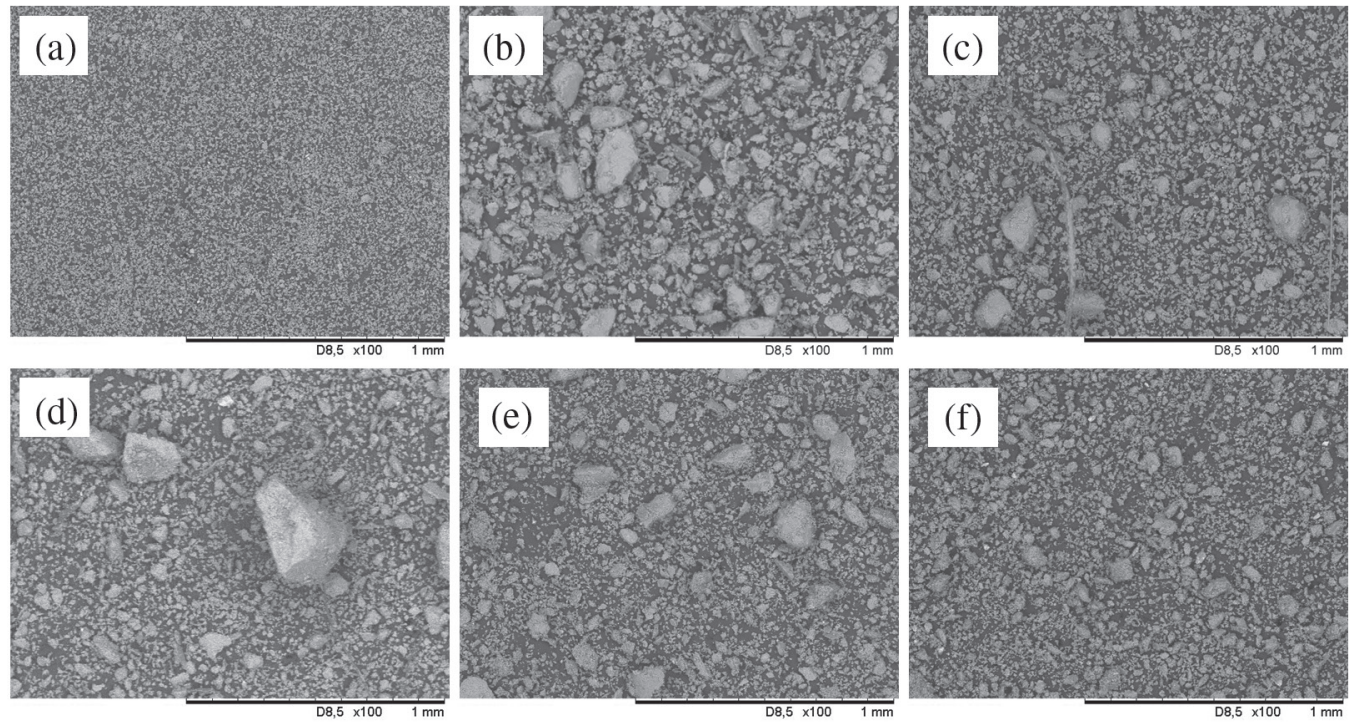

Figure 5. SEM image (focus 8.5; magnification $\times 100$ ) for (a) Bent; (b) La1Bent; (c) La2Bent; (d) LaFeBent; (e) PetBent; (f) La2PetBent.

the presence of particles of a larger size was still observed for certain samples, mainly for LaFeBent.

According to all the characterizations that were performed, it is believed that the commercial precursor clay, PetBent, is a smectite with a predominance of montmorillonite. However, there are clear differences between its chemical composition (percentage of $\mathrm{Fe}_{2} \mathrm{O}_{3}$ ) and textural properties (surface area, pore volume, and average pore diameter) and those of the reference clay, Bent. Modifications with lanthanum and iron by the ion exchange procedure did not alter the crystalline phases, but changed the average pore diameter. After the characterizations were performed, the materials were evaluated in kinetic and equilibrium studies of phosphate adsorption.

\section{Study of the effect of $\mathrm{pH}$ on phosphate adsorption}

The results of the adsorption of inorganic phosphate at different $\mathrm{pH}$ values are shown in Figure 6. The $\mathrm{pH}$ range of 4.0-10.0 was evaluated since most aquatic environments are within this range. The amount of phosphate adsorbed by the prepared materials was not influenced by $\mathrm{pH}$ in the evaluated range and, thus, all of them may be applied in a variety of environments without modifying their adsorption capacity.

According to Brazilian legislation, given by Conselho Nacional do Meio Ambiente (CONAMA) Resolution No. $357 / 2005,{ }^{57}$ which provides for the classification of water bodies and environmental guidelines for their classification, as well as establishes the conditions and standards for effluent discharge, and other measures, one of the quality parameters for water is the $\mathrm{pH}$ level. For fresh and brackish water, the targets of this work, the $\mathrm{pH}$ range considered as

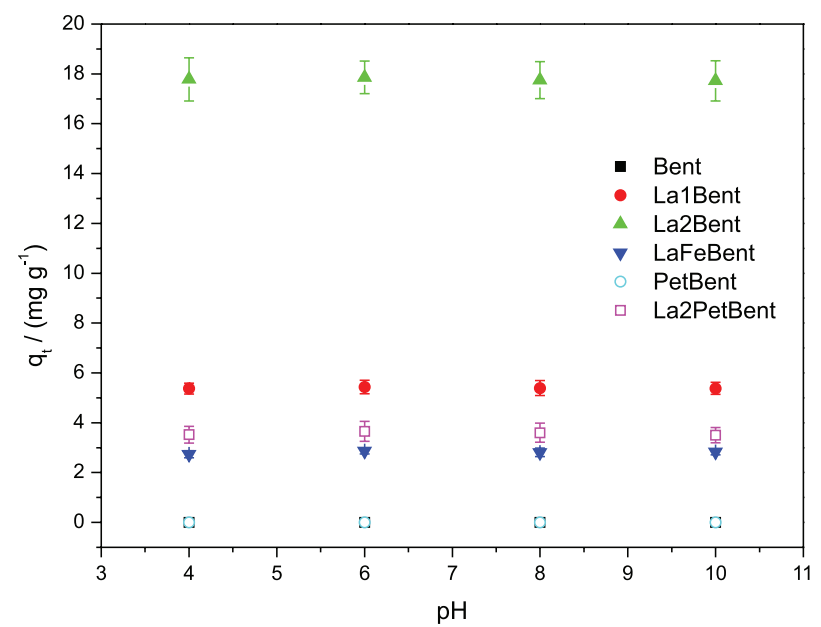

Figure 6. Phosphate adsorption by modified clays under different $\mathrm{pH}$.

standard is 6.0-9.0. Therefore, the kinetic and adsorption studies were conducted at the lower limit of this standard range.

\section{Kinetic study of phosphate adsorption}

Figure 7 illustrates the curves for the kinetic study of the materials modified with lanthanum and iron. The rate of phosphate adsorption was faster in the first $24 \mathrm{~h}$, but after a period of $72 \mathrm{~h}$, the adsorption reached equilibrium.

It is important to note that the unmodified clay minerals (Bent and PetBent) were evaluated in the kinetic study using a control test with the phosphate solution. During the established period, the materials did not adsorb or desorb phosphate in any extension.

The calculated kinetic parameters are presented in Table 2. For La1Bent clay, the phosphate adsorption 




Figure 7. Kinetics curves for inorganic phosphate adsorption on the modified clays.

capacity was $2.74 \mathrm{mg} \mathrm{g}^{-1}$ in $12 \mathrm{~h}, 4.08 \mathrm{mg} \mathrm{g}^{-1}$ in $24 \mathrm{~h}$, $5.40 \mathrm{mg} \mathrm{g}^{-1}$ in $72 \mathrm{~h}^{2}$ and $5.52 \mathrm{mg} \mathrm{g}^{-1}$ in $96 \mathrm{~h}$. La2Bent clay adsorbed the highest amounts of phosphate: $9.54 \mathrm{mg} \mathrm{g}^{-1}$ in $12 \mathrm{~h}, 13.38 \mathrm{mg} \mathrm{g}^{-1}$ in $24 \mathrm{~h}, 16.23 \mathrm{mg} \mathrm{g}^{-1}$ in $72 \mathrm{~h}$, and $16.29 \mathrm{mg} \mathrm{g}^{-1}$ in $96 \mathrm{~h}$. For LaFeBent clay, the phosphate adsorption capacity was $1.81 \mathrm{mg} \mathrm{g}^{-1}$ in $12 \mathrm{~h}, 2.35 \mathrm{mg} \mathrm{g}^{-1}$ in $24 \mathrm{~h}, 2.97 \mathrm{mg} \mathrm{g}^{-1}$ in $72 \mathrm{~h}$, and $3.11 \mathrm{mg} \mathrm{g}^{-1}$ in $96 \mathrm{~h}$. For La2PetBent clay, the phosphate adsorption capacity attained the values of $2.16 \mathrm{mg} \mathrm{g}^{-1}$ in $12 \mathrm{~h}, 3.09 \mathrm{mg} \mathrm{g}^{-1}$ in $24 \mathrm{~h}, 4.12 \mathrm{mg} \mathrm{g}^{-1}$ in $72 \mathrm{~h}$, and $4.14 \mathrm{mg} \mathrm{g}^{-1}$ in $96 \mathrm{~h}$. The unmodified clay minerals, Bent and PetBent, were not evaluated with the kinetic models listed in Table 2 since they did not adsorb phosphate. It is worth mentioning that the greatest amount of the adsorption occurred in the first $24 \mathrm{~h}$, and the equilibrium was reached between 72 and $96 \mathrm{~h}$.
For the four clays (La1Bent, La2Bent, LaFeBent, and La2PetBent), the model that better fit the experimental data was the pseudo-second order, as suggested by the coefficients of determination $\left(\mathrm{R}^{2}\right)$, which were close to unity and indicate a linear relation between $\left(\mathrm{t} / \mathrm{q}_{\mathrm{t}}\right)$ and $\mathrm{t}$. In general, the pseudo-second order model describes well the behavior of the ion adsorption on solids over the entire contact time with the solution and relates this process to the occurrence of chemisorptions..$^{40,42,43,58}$

The adsorption rate decreased in the following order for the clay minerals: La2Bent, La1Bent, La2PetBent, and $\mathrm{LaFeBent}\left(1.55,0.44,0.32\right.$, and $\left.0.28 \mathrm{mg} \mathrm{g}^{-1} \mathrm{~h}^{-1}\right)$. As is evident, there was a direct relation between the adsorption rate of the clays and their lanthanum percentage.

The results for the adsorption behavior and characterization of the materials reveal that the textural properties may have more strongly influenced the chemical modification process. The difference in the pore size of the precursor clay minerals, Bent $(100 \AA)$ and PetBent $(60 \AA)$, may have influenced the ion exchange modification since the diffusion of the ionic solution through the material with larger pores is easier. On the other hand, the percentage of incorporation of $\mathrm{La}^{3+}$ and $\mathrm{Fe}^{3+}$ seems to have determined the adsorption capacity. It is possible that the influence of the textural properties was masked by the important role of the $\mathrm{La}^{3+} / \mathrm{Fe}^{3+}$ content on the adsorption behavior of the materials.

\section{Phosphate adsorption studies}

Figure 8 illustrates the adsorption isotherms of the studied materials. The initial concentration of phosphate

Table 2. Parameters from kinetic phosphate adsorption modeling

\begin{tabular}{|c|c|c|c|c|c|c|c|}
\hline Clay & Kinetic model & $\mathrm{R}^{2}$ & $\mathrm{q}_{\mathrm{e}}{ }^{\mathrm{a}} /\left(\mathrm{mg} \mathrm{g}^{-1}\right)$ & $\mathrm{k}_{1} / \mathrm{h}^{-1}$ & $\mathrm{k}_{2} /\left(\mathrm{g} \mathrm{mg}^{-1} \mathrm{~h}^{-1}\right)$ & $\mathrm{C} /\left(\mathrm{mg} \mathrm{g}^{-1}\right)$ & $\mathrm{k}_{\mathrm{int}} /\left(\mathrm{mg} \mathrm{g}^{-1} \mathrm{~h}^{-1 / 2}\right)$ \\
\hline & pseudo-first order model & 0.960 & 5.13 & 0.05 & - & - & - \\
\hline \multirow[t]{3}{*}{ La1Bent } & pseudo-second order model & 0.995 & 6.37 & - & 0.01 & - & - \\
\hline & intra-particle diffusion & 0.953 & - & - & - & 0.20 & 0.655 \\
\hline & pseudo-first order model & 0.94 & 16.60 & 0.07 & - & - & - \\
\hline \multirow[t]{3}{*}{ La2Bent } & pseudo-second order model & 0.996 & 19.23 & - & 0.004 & - & - \\
\hline & intra-particle diffusion & 0.917 & - & - & - & 1.17 & 1.977 \\
\hline & pseudo-first order model & 0.981 & 2.52 & 0.04 & - & - & - \\
\hline \multirow[t]{3}{*}{ LaFeBent } & pseudo-second order model & 0.995 & 3.51 & - & 0.02 & - & - \\
\hline & intra-particle diffusion & 0.924 & - & - & - & 0.16 & 0.369 \\
\hline & pseudo-first order model & 0.939 & 4.59 & 0.06 & - & - & - \\
\hline \multirow[t]{2}{*}{ La2PetBent } & pseudo-second order model & 0.995 & 4.95 & - & 0.01 & - & - \\
\hline & intra-particle diffusion & 0.956 & - & - & - & 0.08 & 0.516 \\
\hline
\end{tabular}

avalues determined from the equations of the kinetic models presented in Supplementary Information section. $\mathrm{R}^{2}$ : coefficient of determination; $\mathrm{q}_{\mathrm{e}}$ : amount of phosphate adsorbed at the equilibrium; $\mathrm{k}_{1}$ : rate constant of pseudo-first order adsorption; $\mathrm{k}_{2}$ : pseudo-second order rate constant; C: intercept, a constant related to the thickness of the boundary layer; $\mathrm{k}_{\text {int }}$ : rate of intra-particle diffusion. 


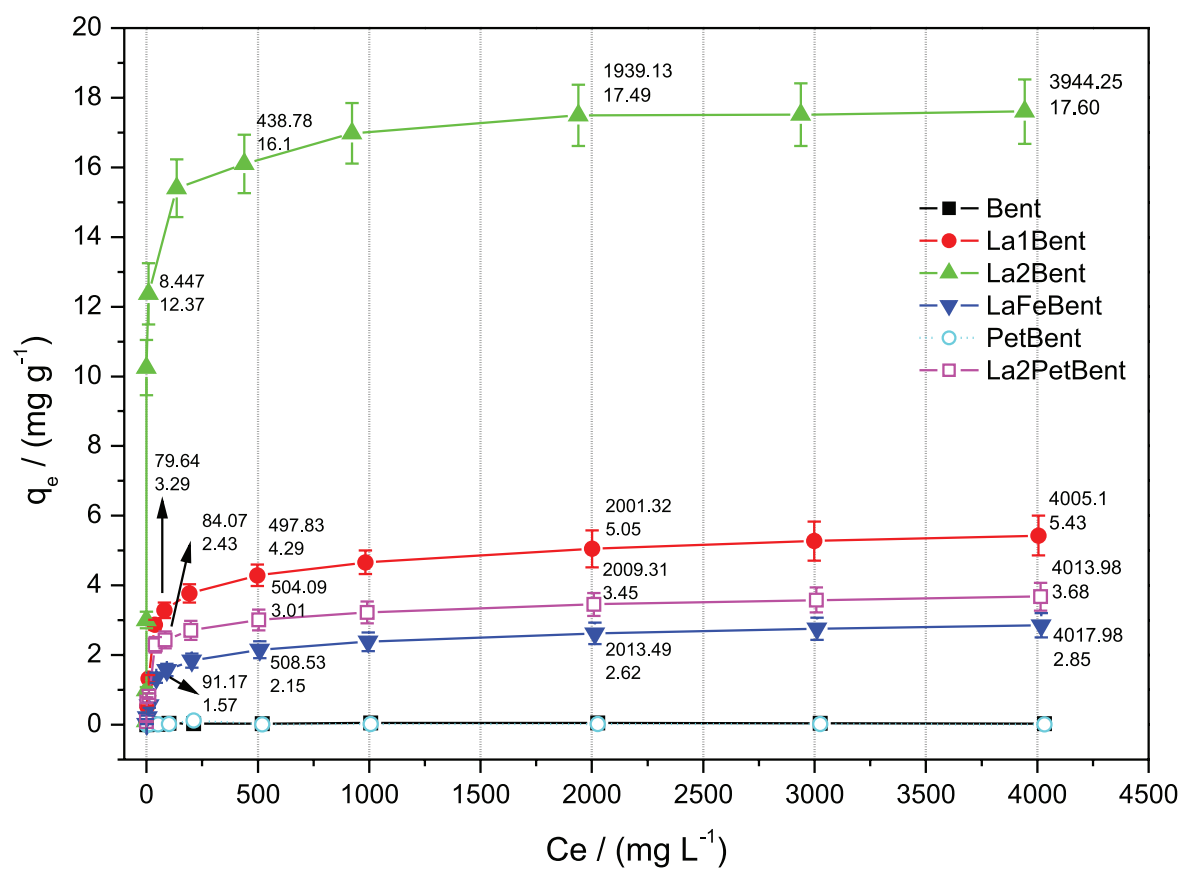

Figure 8. Adsorption isotherms for phosphate on modified clays.

varied from 0.49 to $4032.24 \mathrm{mg} \mathrm{L}^{-1}$. This large range was necessary to achieve the saturation of the adsorbent material in order to build the adsorption isotherms and to recognize phosphate's exact adsorption profile.

The clay that adsorbed the highest amount of phosphate was La2Bent: $17.6 \pm 0.9 \mathrm{mg}$ of inorganic phosphate per gram of the material. This behavior can be directly correlated to the content of lanthanum in the material, expressed as $4.00 \%$ of $\mathrm{La}_{2} \mathrm{O}_{3}$. This statement is supported by the comparison between the two lanthanum containing clays: La1Bent contains $2.27 \%$ of $\mathrm{La}_{2} \mathrm{O}_{3}$, which value is almost half of the La2Bent lanthanum content, and has an adsorption capacity of approximately $5.5 \mathrm{mg} \mathrm{PO}_{4} \mathrm{~g}^{-1}$, which is approximately three times less.

The unmodified clay minerals (Bent and PetBent) were also evaluated in the phosphate adsorption studies through the control test with phosphate solution, verifying that the materials did not adsorb nor desorb phosphate.

The results for the adsorption parameters are presented in Table 3. The model that better described the phosphate adsorption process for the modified clay minerals (La1Bent, La2Bent, LaFeBent, and La2PetBent) was the Langmuir one, with the $\mathrm{R}^{2}$ closest to one. From the Langmuir model, the slope and intercept of the plot $\left(\mathrm{Q}_{\max } ; \mathrm{K}_{\mathrm{L}}\right)$ as well as the $R_{L}$ values were determined. For all the modified clay minerals, the $R_{L}$ reached values between zero and one, thereby indicating a favorable adsorption process. For the clay La2Bent, the maximum adsorption capacity obtained for the monolayer $\left(\mathrm{Q}_{\max }\right)$ was $17.86 \mathrm{mg} \mathrm{g}^{-1}$; moreover, the equilibrium parameter $\left(R_{L}\right)$ was found to be 0.003 , which indicates a favorable adsorption process for La2Bent. The results obtained are corroborated by many adsorption

Table 3. Adsorption isothermal constants for phosphate on modified clays

\begin{tabular}{|c|c|c|c|c|c|c|c|}
\hline Clay & Model & $\mathrm{R}^{2}$ & $\mathrm{Q}_{\max } /\left(\mathrm{mg} \mathrm{g}^{-1}\right)$ & $\mathrm{K}_{\mathrm{L}} /\left(\mathrm{L} \mathrm{mg}^{-1}\right)$ & $\mathrm{R}_{\mathrm{L}}$ & $\mathrm{K}_{\mathrm{F}}$ & $\mathrm{n}$ \\
\hline \multirow{2}{*}{ La1Bent } & Langmuir & 0.998 & 5.43 & 0.02 & 0.016 & - & - \\
\hline & Freudlich & 0.900 & - & - & & 0.43 & 2.79 \\
\hline \multirow{2}{*}{ La2Bent } & Langmuir & 0.999 & 17.86 & 0.09 & 0.003 & - & - \\
\hline & Freudlich & 0.623 & - & - & & 4.22 & 4.90 \\
\hline \multirow{2}{*}{ LaFeBent } & Langmuir & 0.998 & 2.86 & 0.01 & 0.024 & - & - \\
\hline & Freudlich & 0.842 & - & - & & 0.10 & 2.10 \\
\hline \multirow{2}{*}{ La2PetBent } & Langmuir & 0.998 & 3.66 & 0.02 & 0.013 & - & - \\
\hline & Freudlich & 0.842 & - & - & & 0.48 & 3.53 \\
\hline
\end{tabular}

$\mathrm{R}^{2}$ : coefficient of determination; $\mathrm{Q}_{\max }$ : maximum adsorption capacity; $\mathrm{K}_{\mathrm{L}}$ : Langmuir equilibrium constant; $\mathrm{R}_{\mathrm{L}}$ : equilibrium parameter; $\mathrm{K}_{\mathrm{F}}$ : Freundlich constant; n: Freundlich intensity parameter.. 
processes using lanthanum, described in the literature, ${ }^{58}$ which were explained by the Langmuir model.

The values obtained for the four adsorbents prepared in this work reveal that La2Bent has the best adsorption capacity. Thus, considering that La2Bent is 1.7 times more concentrated than La1Bent, the difference from $2.27 \pm 0.02$ to $4.00 \pm 0.03 \%$ in $\mathrm{La}_{2} \mathrm{O}_{3}$ content increased the adsorption capacity by a factor of 3.3 .

A comparison of Bent and PetBent clays in the process of phosphate adsorption reveals certain similarities and differences between them. Initially, both of them do not adsorb phosphate without the process of modification, which is what was expected for cationic clays containing $\mathrm{Na}^{+}$and $\mathrm{Ca}^{2+}$; since these cations do not interact strongly with the phosphate anion. With regard to the chemical composition of bentonites, PetBent contains a higher amount of $\mathrm{Fe}_{2} \mathrm{O}_{3}$ $(8.06 \pm 0.02 \%)$ than Bent $(3.83 \pm 0.01 \%)$. The $\mathrm{Fe}^{3+}$ ions, which are located in the tetrahedral sheets composing the 2:1 layer of the clay minerals montmorillonite, ${ }^{22}$ are not available for the ion exchange process as the cations of the interlamellar layer. Therefore these cations are not available to adsorb phosphate. They also do not desorb phosphate to the solution after the completion of the time period studied.

However, in terms of their textural properties, there are significant differences in the specific surface area, 31 and $103 \mathrm{~m}^{2} \mathrm{~g}^{-1}$, and in the mean pore diameter, 100 and $60 \AA$, for Bent and PetBent, respectively. Therefore, these characteristics may have influenced the modification process of the clay minerals and indirectly influenced their phosphate adsorption capacity. For example, the difference in pore size may have influenced the extension of the ion exchange process, thereby leading to a difference in the chemical composition of the modified clay minerals.

Comparing the modified La2Bent and La2PetBent materials, which were modified under the same conditions, the values of $\mathrm{Q}_{\max }$ (17.86 and $3.66 \mathrm{mg} \mathrm{g}^{-1}$, respectively) show that the precursor clay had a great effect on the phosphate adsorption capacity. This was because La2Bent incorporated $4.00 \pm 0.03 \% \mathrm{La}_{2} \mathrm{O}_{3}$, while La2PetBent incorporated $2.65 \pm 0.03 \%$.

Although both Bent and PetBent have similar CEC values, the process of purification conducted on Bent may have affected the ion exchange by lanthanum and iron. The elimination of impurities such as quartz produced a more pure clay mineral, which is richer in montmorillonite and more suitable for the cation exchange procedure. ${ }^{49,50}$

Analysis of the water of the Jacarepaguá Lagoon (Rio de Janeiro, Brazil)

Table 4 presents the results for the chemical analyses of some important parameters for the study of the Jacarepaguá Lagoon water and the comparison with those established in the CONAMA Resolution No. 357/2005 (Brazilian legislation). ${ }^{57}$

Table 4. Results of water quality parameters of the Jacarepaguá Lagoon and comparison with Brazilian legislation

\begin{tabular}{|c|c|c|}
\hline Parameter & Value & $\begin{array}{c}\text { Pattern (CONAMA } \\
357: 2005)^{57} \\
\end{array}$ \\
\hline Temperature / K & $304.1 \pm 0.2$ & - \\
\hline $\mathrm{pH}$ & $9.96 \pm 0.41$ & $6.5-8.5$ \\
\hline Conductivity / $\left(\mathrm{mS} \mathrm{cm}^{-1}\right)$ & $8.51 \pm 0.04$ & - \\
\hline Salinity $/ \% o$ & $4.9 \pm 0.1$ & $0.5-30$ \\
\hline Dissolved oxygen / $\left(\mathrm{mg} \mathrm{L}^{-1}\right)$ & $1.9 \pm 0.1$ & $>4.0$ \\
\hline $\mathrm{SPM}^{\mathrm{b}} /\left(\mathrm{mg} \mathrm{L}^{-1}\right)$ & $93.25 \pm 2.47$ & - \\
\hline $\mathrm{Cl}^{-} /\left(\mathrm{g} \mathrm{L}^{-1}\right)$ & $2.68 \pm 0.30$ & - \\
\hline $\mathrm{NO}_{3}^{-} /\left(\mathrm{mg} \mathrm{L}^{-1}\right)$ & $5.37 \pm 0.08$ & - \\
\hline Nitrate-N / $\left(\mathrm{mg} \mathrm{L}^{-1}\right)$ & $1.21 \pm 0.02$ & 0.70 (nitrate, $\mathrm{N}$ ) \\
\hline $\mathrm{SO}_{4}{ }^{2-} /\left(\mathrm{mg} \mathrm{L}^{-1}\right)$ & $383.85 \pm 4.45$ & - \\
\hline $\begin{array}{l}\text { Total phosphorus (TP) / } \\
\left(\mathrm{mg} \mathrm{L}^{-1}\right)\end{array}$ & $1.34 \pm 0.02$ & 0.186 (phosphorus, $\mathrm{P}$ ) \\
\hline 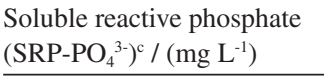 & $0.41 \pm 0.01$ & - \\
\hline \multicolumn{3}{|c|}{$\begin{array}{l}\text { a Parts per thousand or } \mathrm{g} \mathrm{kg}^{-1} \text {; }{ }^{\mathrm{b}} \text { suspended particulate material; }{ }^{\mathrm{c}} \mathrm{SRP} \\
\text { expressed as phosphate concentration }\left(\mathrm{PO}_{4}{ }^{3-}\right) \text {. To convert to concentration } \\
\text { in terms of phosphorus }(\mathrm{P}) \text {, the relationship between the molar masses } \\
\text { must be used }\left(\mathrm{PO}_{4}{ }^{3-} / \mathrm{P}=94.97 \mathrm{~g} \mathrm{~mol}^{-1} / 30.97 \mathrm{~g} \mathrm{~mol}^{-1}=3.07\right) \text {. }\end{array}$} \\
\hline
\end{tabular}

According to the value of salinity equal to $4.9 \%$, the water of the Jacarepaguá Lagoon was classified as brackish, taking into consideration Resolution No. 357/2005 of CONAMA. ${ }^{57}$ Brackish waters present salinity higher than $0.5 \%$ and less than $30 \%$. To be classified as class 2 brackish water, which can be used for amateur fishing and secondary contact recreation, the following conditions and quality standards were established in Brazil: $\mathrm{pH} 6.5$ to 8.5; dissolved oxygen: greater than $4 \mathrm{mg} \mathrm{L}^{-1} \mathrm{O}_{2}$; substances that produce color, odor, and turbidity: virtually absent; total phosphorus: $0.186 \mathrm{mg} \mathrm{L}^{-1} \mathrm{P}$; nitrate: $0.70 \mathrm{mg} \mathrm{L}^{-1} \mathrm{~N}$. The parameters in Table 4 show that the water of the Jacarepaguá Lagoon did not present the values of $\mathrm{pH}$, dissolved oxygen, color, total phosphorus, and nitrate according to the conditions established by Brazilian legislation. ${ }^{57}$ Consequently, the macronutrients phosphorus and nitrate do not match the water quality standards and thus contribute to the process of eutrophication of the Jacarepaguá Lagoon. This finding is in agreement with studies that describe the eutrophication of aquatic environments, where undesirable consequences appear with the proliferation of aquatic macrophytes and cyanobacteria bloom, which are capable of producing toxins. ${ }^{959}$ Studies indicate the flowering of these microorganisms in the Jacarepaguá Lagoon, particularly of 
toxic cyanobacteria Microcystis,, 5 which can accumulate in fish and cause a serious risk to the health of the general population. In addition, studies also find growth of pathogenic bacteria that are resistant to antibiotics. ${ }^{4}$

Generally, lakes are classified into four categories related to the trophic level: oligotrophic, mesotrophic, eutrophic, and hypertrophic, with the latter being the worst water quality. Different parameters are needed to compose the classification, with measurements being conducted over the years. Analyzing the main cause of the process, when phosphorus concentration is in the $0.016-0.386 \mathrm{mg} \mathrm{L}^{-1}$ range, the aquatic environment is considered eutrophic and when it is in the $0.750-1.200 \mathrm{mg} \mathrm{L}^{-1}$ range, it is considered hypereutrophic. ${ }^{59}$ Thus, in accordance with this parameter, the Jacarepaguá Lagoon can be considered a hypereutrophic aquatic environment.

One of the main strategies for controlling the primary productivity in lakes is reducing the excessive contribution of phosphorus and environmental remediation with phosphate adsorbing materials. For this reason, apart from monitoring studies on these urban lagoon systems, research on environmental remediation is pressing.

\section{Adsorption test on real sample in laboratory: Jacarepaguá Lagoon (Rio de Janeiro, Brazil)}

Figure 9 depicts the phosphate quantity $\left(\mathrm{q}_{\mathrm{t}}\right)$ adsorbed as a function of time from the actual water sample of the Jacarepaguá Lagoon (Rio de Janeiro, Brazil). The modified clay minerals were efficient in the removal of phosphate from the collected sample. From the water volume used and its phosphate concentration $(50 \mathrm{~mL}$, considering the initial concentration of $0.41 \pm 0.01 \mathrm{mg} \mathrm{L}^{-1}$ ), a mass of $0.02 \mathrm{mg}$ of phosphate would be available to be adsorbed. According to the determined adsorption capacities, $0.005 \mathrm{~g}$ of the materials would be able to adsorb the following phosphate masses: La1Bent: $0.02715 \mathrm{mg}$; La2Bent: $0.0893 \mathrm{mg}$; LaFeBent: $0.0143 \mathrm{mg}$; La2PetBent: $0.0183 \mathrm{mg}$. Thus, for the materials La1Bent and La2Bent a smaller mass could have been used since the capacity of adsorption is superior to the phosphate mass in $50 \mathrm{~mL}$ of the actual water sample tested. In order to standardize the same material mass, $0.005 \mathrm{~g}$ was used for all materials in the test. The maximum adsorption capacity of the materials was determined in the equilibrium study, which has already been previously presented.

After the adsorption treatment with each material, the concentration values for SRP- $\mathrm{PO}_{4}{ }^{3-}$ were: La1Bent: $0.04 \mathrm{mg} \mathrm{L}^{-1}$; La2Bent: $0.04 \mathrm{mg} \mathrm{L}^{-1}$; LaFeBent: $0.12 \mathrm{mg} \mathrm{L}^{-1}$; and La2PetBent: $0.06 \mathrm{mg} \mathrm{L}^{-1}$. Thus, a significant improvement was achieved in relation to the initial concentration of SRP-PO ${ }_{4}{ }^{3-}, 0.41 \pm 0.01 \mathrm{mg} \mathrm{L}^{-1}$. This reduction in reactive phosphate was extremely important since it is the main form of phosphorus assimilation by aquatic plants, which goes out of control and leads to the process of eutrophication. However, even with adsorption of SRP-PO ${ }_{4}^{3-}$, the concentration of total phosphorus (TP) would still be above the CONAMA specification. ${ }^{57}$ This high TP of the Jacarepaguá Lagoon indicates that it suffered a cyanobacteria bloom near to the date of collection, and the phosphorus present in the cells will only be available when they begin to degrade, becoming SRP- $\mathrm{PO}_{4}{ }^{3-}$. The adsorbent materials of this work only act in the reduction of SRP-PO ${ }_{4}^{3-}$, which is of extreme importance as this will

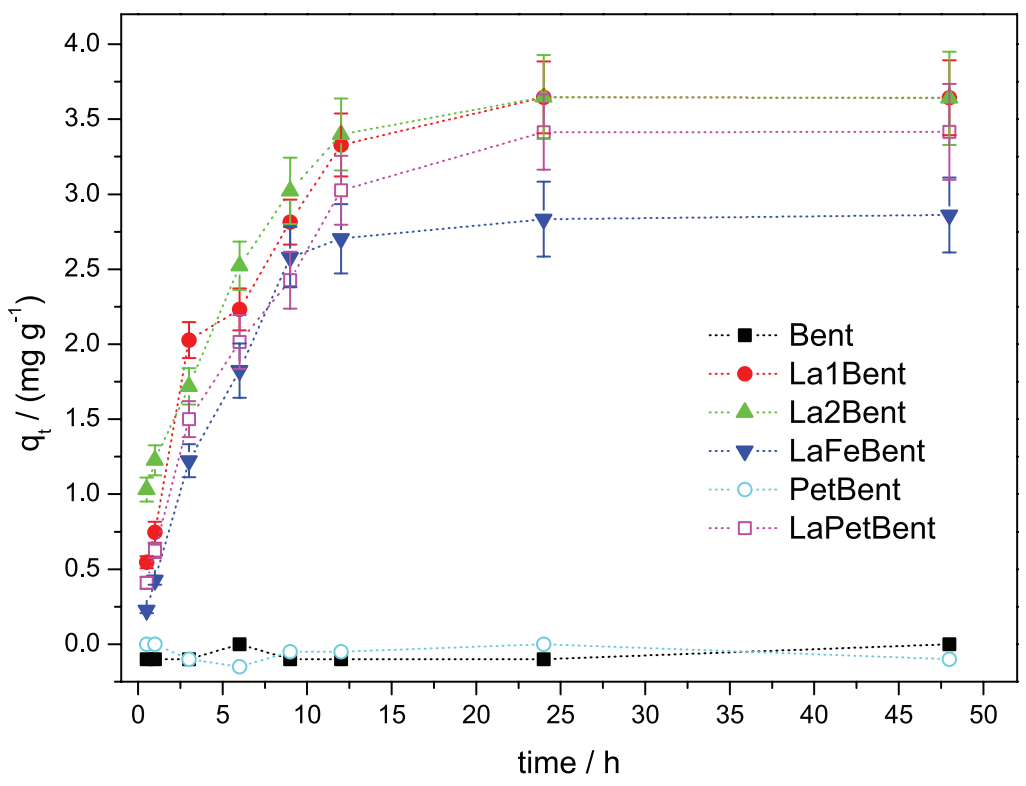

Figure 9. Phosphate adsorption kinetic curves for water of the Jacarepaguá Lagoon. 
limit the growth of algae, consequently reducing TP and improving water quality. It is worth informing that there are studies on remediation of lakes with other possibilities of restoration with TP as the target. ${ }^{3,60}$

Final aliquots after the $48 \mathrm{~h}$ procedure were analyzed for the determination of chloride, nitrate, and sulfate. Their concentrations were unchanged, thereby demonstrating that the material does not adsorb such anions. Therefore, the materials were selective for phosphate adsorption.

\section{Comparison with adsorbents from other studies}

Table 5 presents the maximum adsorption capacity of inorganic phosphate for the clay minerals studied here and for some materials reported in the literature. A comparison of our material and the conditions of evaluation is made here in order to conclude about its perspective.

A research group in China ${ }^{61}$ has evaluated a material modified with lanthanum and aluminum LaAlPILC (La-modified pillared clay). The material showed good adsorption capacity (13.022 $\mathrm{mg} \mathrm{g}^{-1}$ ) when compared to other materials reported in the literature. However, an evaluation of the $\mathrm{pH}$ range from 3.0 to 8.0 showed a great decrease in the adsorptive capacity in $\mathrm{pH}$ higher than 5.0, which was not a problem for the clay mineral studied here. In addition, certain studies ${ }^{18-21}$ have evaluated the $\mathrm{pH}$ level and hardness of water, indicating the possibility of toxicity due to the bioavailability of aluminum. Taking into account

Table 5. Comparison of adsorbents

\begin{tabular}{|c|c|c|c|c|}
\hline Adsorbent & $\mathrm{Q}_{\max } /\left(\mathrm{mg} \mathrm{g}^{-1}\right)$ & $\mathrm{La} / \mathrm{Fe}$ content & Experimental condition & Reference \\
\hline $\begin{array}{l}\text { LaAlPILC } \\
\text { (La-modified } \\
\text { pillared clay) }\end{array}$ & 13.022-P removal & not found in the study & $\begin{array}{c}\text { batch time: } 12 \mathrm{~h} \\
\text { shaking: } 170 \mathrm{rpm} \\
\text { phosphate range: } 2.5 \text { to } 50 \mathrm{mg} \mathrm{L} \\
\text { ratio solid/solution: } 0.0375 \mathrm{~g} / 50 \mathrm{~mL} \\
\text { temperature: } 25 \text { to } 35{ }^{\circ} \mathrm{C} \\
\text { pH: } 5.0 \text { (determination of } \mathrm{Q}_{\max } \text { ) } \\
\text { pH range: } 3.0 \text { to } 8.0\end{array}$ & 61 \\
\hline NT-25La & 14.0 & $\begin{array}{l}\text { reported to one half unit cell: } \\
\left(\mathrm{Al}_{1.13} \mathrm{Fe}_{0.34} \mathrm{Mg}_{0.32}\right)_{\mathrm{VI}}\left(\mathrm{Si}_{3.84} \mathrm{Al}_{0.16}\right)_{\mathrm{IV}} \\
\mathrm{O}_{10}(\mathrm{OH})_{2}\left(\mathrm{La}_{0.11} \mathrm{~K}_{0.02}\right)\end{array}$ & $\begin{array}{c}\text { batch time: } 1 \text { to } 90 \mathrm{~min} \\
\text { magnetic stirring } \\
\text { phosphate range: } 0.5 \text { to } 80 \mathrm{mg} \mathrm{L}^{-1} \\
\text { ratio solid/solution: } 0.0375 \mathrm{~g} / 50 \mathrm{~mL} \\
\text { temperature: } 298 ; 313 \text { and } 373 \mathrm{~K} \\
\text { pH: } 6.0 \text { (determination of } \mathrm{Q}_{\max } \text { ) } \\
\text { pH range: } 3.0 \text { to } 9.0\end{array}$ & 28 \\
\hline $\begin{array}{l}\text { SCC (sun coral powder } \\
\text { material) }\end{array}$ & 9.597-P removal & $\begin{array}{l}\text { no modification was performed with } \\
\text { lanthanum and iron }\end{array}$ & $\begin{array}{c}\text { batch time: } 20 \mathrm{~min} \\
\text { orbital shaker: } 150 \mathrm{rpm} \\
\text { phosphate range: } 0 \text { to } 18.4 \mathrm{mg} \mathrm{P} \mathrm{L}{ }^{-1} \\
\text { ratio solid/solution: } 0.4 \mathrm{~g} / 100 \mathrm{~mL} \\
\text { temperature: } 23.6 \text { to } 40.4{ }^{\circ} \mathrm{C} \\
\text { pH: } 7.0 \text { (determination of } \mathrm{Q}_{\max } \text { ) } \\
\text { pH range: } 5.32 \text { to } 8.68\end{array}$ & 62 \\
\hline $\begin{array}{l}\text { Phoslock (Phoslock } \\
\text { Water Solutions Pty } \\
\text { Ltd, PWS) }\end{array}$ & 9.5-10.5-P removal & $0.058 \% \mathrm{La}_{2} \mathrm{O}_{3}$ & $\begin{array}{c}\text { batch time: } 5 \mathrm{~h} \\
\text { shaking water bath } \\
\text { phosphate range: } 10 \mathrm{mg} \mathrm{P} \mathrm{L}{ }^{-1} \\
\text { ratio solid/solution: } 0.01-1 \mathrm{~g} / 200 \mathrm{~mL} \\
\text { temperature: } 10-35^{\circ} \mathrm{C} \\
\text { pH: } 5.4 \text { (determination of } \mathrm{Q}_{\max } \text { ) } \\
\text { pH range: } 3.0 \text { to } 8.0\end{array}$ & 24 \\
\hline Phoslock $^{\circledR}$ (CSIRO) & 9.1-P removal & $\begin{array}{c}\text { 4.4\% } \mathrm{La} \text { and } 0.75 \% \mathrm{Fe} \\
10.32 \% \mathrm{La}_{2} \mathrm{O}_{3} \text { and } 2.14 \% \mathrm{Fe}_{2} \mathrm{O}_{3}\end{array}$ & $\begin{array}{l}\text { batch time: } 1-12 \text { days } \\
\text { shaking } \\
\text { phosphate range: } 620 \mu \mathrm{g} \mathrm{P} \mathrm{L}{ }^{-1} \\
\text { ratio solid/P }(\mathrm{m} / \mathrm{m}): 0-200 ; \\
\text { solution volume: } 50 \mathrm{~mL} \\
\text { temperature: }- \\
\text { pH: } 7.3-8.5 \text { (lakes) }\end{array}$ & 26 \\
\hline La1Bent & 5.43 & $2.27 \% \mathrm{La}_{2} \mathrm{O}_{3}$ and $3.83 \% \mathrm{Fe}_{2} \mathrm{O}_{3}$ & \multirow{4}{*}{$\begin{array}{c}\text { batch time: } 1 \text { to } 96 \mathrm{~h} \\
\text { horizontal shaker: } 150 \mathrm{rpm} \\
\text { phosphate range: } 0.49 \text { to } 4032.25 \mathrm{mg} \mathrm{L}{ }^{-1} \\
\text { ratio solid/solution: } 0.25 \mathrm{~g} / 50 \mathrm{~mL} \\
\text { temperature: } 296 \pm 2 \mathrm{~K} \\
\text { pH: } 6.0 \text { (determination of } \mathrm{Q}_{\max } \text { ) } \\
\text { pH range: } 4.0 \text { to } 10.0\end{array}$} & \multirow{4}{*}{ this work } \\
\hline La2Bent & 17.86 & $4.00 \% \mathrm{La}_{2} \mathrm{O}_{3}$ and $3.71 \% \mathrm{Fe}_{2} \mathrm{O}_{3}$ & & \\
\hline LaFeBent & 2.86 & $2.17 \% \mathrm{La}_{2} \mathrm{O}_{3}$ and $4.69 \% \mathrm{Fe}_{2} \mathrm{O}_{3}$ & & \\
\hline La2PetBent & 3.66 & $2.65 \% \mathrm{La}_{2} \mathrm{O}_{3}$ and $7.66 \% \mathrm{Fe}_{2} \mathrm{O}_{3}$ & & \\
\hline
\end{tabular}

$\mathrm{Q}_{\max }$ : maximum adsorption capacity; $\mathrm{P}$ removal: phosphorus removal. 
that the $\mathrm{pH}$ range of lakes is usually in the 6.0-10.0 range, the Chinese material may have limited application.

In relation to research conducted in Brazil, Kuroki et al. ${ }^{28}$ reported the investigation of a bentonite modified with lanthanum, called NT-25 La, which presented the high adsorption capacity of $14.0 \mathrm{mg} \mathrm{g}^{-1}$ compared with the capacities presented by similar materials already reported in the literature. In the study, magnetic stirring was used, which may not simulate the water movement in a lagoon aquatic environment. It may also have contributed to the fast adsorption of phosphate from the solution. In this study, we obtained a lanthanum-modified bentonite, La2Bent, with a better adsorption capacity of $17.86 \mathrm{mg} \mathrm{g}^{-1}$.

Another research group evaluated the removal of phosphate through the application of coral powder called SCC. ${ }^{62}$ That work investigated the removal of phosphate from synthetic water and wastewaters by applying this material with a high concentration of calcium carbonate. However, the study only evaluated the adsorption process in the range of $\mathrm{pH} 5.32$ to 8.68. In the study, the laboratory application on municipal sewage effluent obtained after biological treatment was evaluated. It would be interesting to verify the application and behavior of the studied materials in a water sample from eutrophic lakes. Due to the $\mathrm{pH}$ characteristic of the water in eutrophic aquatic environments, it would be important to evaluate up to $\mathrm{pH} 10$.

Comparing the general experimental conditions in our study, aside from the specific ones already commented upon, the kinetic question was evaluated for a greater period of time. It was recognized that much of the adsorption occurs in the first $24 \mathrm{~h}$, but the equilibrium was reached after a longer time.

La2Bent showed the best phosphate adsorption capacity in the amount of $17.86 \mathrm{mg} \mathrm{g}^{-1}$. This material was modified with the highest lanthanum content and from the montmorillonite acquired from Sigma-Aldrich. It is evident from the results for La1Bent and La2Bent materials that the modification with lanthanum was fundamental for the adsorption process. In addition, we investigated the iron contribution in both the bentonite modification process and the adsorption of phosphate.

The material modified with iron and lanthanum (LaFeBent) is promising because it was prepared with a lower concentration of lanthanum, but was still able to reduce the concentration of phosphate in natural water. It is believed that this material may have some economic advantage over the material modified only with lanthanum (Phoslock $\left.{ }^{\circledR}\right)$ due to the lower cost of modification with iron. A disadvantage for our material is the possibility of the environment redox potential to affect the adsorption capacity of phosphate. ${ }^{63}$ Generally, in a eutrophic environment, the dissolved oxygen value is low and iron(III) may be reduced to iron(II) with the release of the phosphate adsorbed into the water.

According to data from the study developed by Reitzel et al. ${ }^{26}$ it is verified that the main commercial material, Phoslock ${ }^{\circledR}$, presents a high content of lanthanum of $10.32 \% \mathrm{La}_{2} \mathrm{O}_{3}$. This, according to the study, leads to the reduction of SRP in the restoration of evaluated lakes. It is believed that this percentage of La is the main differential factor of this material. However, many studies have been developed in the search for formulation as suitable as commercially available.

For the study developed by Haghseresht et al. ${ }^{24}$ the product called Phoslock, supplied by PWS, showed a much lower amount of lanthanum of $0.058 \% \mathrm{La}_{2} \mathrm{O}_{3}$, but presented a similar removal efficiency of 9.5-10.5 $\mathrm{mg} \mathrm{g}^{-1}$ (P removal).

The material prepared from the Brazilian clay, PetBent, already had a higher content of iron in its initial composition and it was modified only with lanthanum. It also possesses an economic advantage because it is a large-scale product in Brazil and its adsorption performance can still be enhanced by an improvement of its textural properties.

\section{Considerations of economic and environmental aspects}

The modification of the materials on a large scale is a good perspective, since it can be performed by a relatively simple procedure of ion exchange under mechanical stirring in room temperature. Aligning to this advantage, there are already some localities in Brazil with production and beneficiation of the precursor material that are showing economic attractiveness. The main deposits are located at Boa Vista, Paraíba State. ${ }^{64,65}$ Data from the literature ${ }^{66}$ on the bentonite market show great occurrence in the United States, as it accounts for the world's highest production of the clay and large investments in this industry for diverse uses, such as oil exploration, animal care, cosmetics, and environmental remediation.

Lanthanum is expensive, so the alternative of a material modified with lanthanum and iron is a promising solution. There are always possibilities for improving the properties of materials through scientific research and technological development projects that aim at creating a better capacity/activity of the material at a lower cost and being environment friendly.

Further, toxicity must be considered; a few studies demonstrating the stability of phosphate adsorbed on lanthanum modified clay indicate low toxicity of the aquatic environment. ${ }^{29,33,34}$ After the application and adsorption process, the material remains at the bottom of the aquatic environment along with the sediment. ${ }^{23}$ It is recognized that long-term studies on lakes treated with modified materials 
should be conducted in order to evaluate bioaccumulation and ecotoxicity, thereby ensuring safe application to aquatic organisms and avoiding harmful effects on human health.

\section{Conclusions}

The La1Bent, La2Bent, LaFeBent, and La2PetBent materials were prepared from the modification of two montmorillonites, Bent and PetBent. The differences in the modification of the materials with lanthanum were possibly related to their chemical composition and certain aspects of textural properties. The results suggest that chemical composition plays an important role in the adsorption of inorganic phosphate. An increase in lanthanum by 1.7 times increased (La1Bent, 2.27\%; La2Bent, 4.00\%; data from Table 1) the adsorption capacity of the SRP by 3.3 times (La1Bent, $5.43 \mathrm{mg} \mathrm{g}^{-1}$; La2Bent, $17.86 \mathrm{mg} \mathrm{g}^{-1}$; data from Table 3). The adsorption of phosphate was better described by the Langmuir model and by the pseudo-second order kinetic model, thereby suggesting the occurrence of a chemisorption process based on the interaction of iron/lanthanum and phosphate ions. The materials were effective for adsorption of inorganic phosphate from a sample of water taken from the Jacarepaguá Lagoon, which has a salinity content that classifies it as brackish and eutrophicated in relation to the phosphate concentration.

The material modified with $\mathrm{La} / \mathrm{Fe}$ (LaFeBent) may be an advantage in economic terms due to the smaller amount of lanthanum used in the modification, which has a higher cost when compared to iron. However, there is the possibility of being affected by the redox potential, especially in the bottom of the eutrophic system which is anoxic. ${ }^{63}$ It can thus reduce the iron(III) to iron(II) with the release of adsorbed phosphate.

It is believed that the materials prepared, characterized, and tested in this work contribute to research for the development of a national product for adsorption of reactive soluble phosphate from eutrophic aquatic environments.

\section{Supplementary Information}

Supplementary information is available, free of charge, at http://jbcs.sbq.org.br as PDF file. It includes a map of the water collection region of the Jacarepaguá Lagoon, mapping images, and EDS spectrum of the modified materials, kinetic models, and linearized adsorption models.

\section{Acknowledgments}

This study was financed in part by the Coordenação de Pessoal de Nível Superior, Brasil (CAPES), Finance Code
001. The authors thank Laboratório Multiusuário/UFRJ for XRD analysis, and LACCO/INT for adsorption-desorption analysis of $\mathrm{N}_{2}$.

\section{References}

1. Elser, J. J.; Curr. Opin. Biotechnol. 2012, 23, 833.

2. Smil, V.; Annu. Rev. Energy Environ. 2000, 25, 53.

3. Lürling, M.; Mackay, E.; Reitzel, K.; Spears, B. M.; Water Res. 2016, 97, 1.

4. Salloto, G. R. B.; Cardoso, A. M.; Coutinho, F. H.; Pinto, L. H.; Vieira, R. P.; Chaia, C.; Lima, J. L.; Albano, R. M.; Martins, O. B.; Clementino, M. M.; PLoS One 2012, 7, e51175.

5. Ferrão-Filho, A. S.; Domingos, P.; Azevedo, S. M. F. O.; Limnologica 2002, 32, 295.

6. Santangelo, J. M.; Rocha, A. M.; Bozelli, R. L.; Carneiro, L. S.; Esteves, F. A.; Estuarine, Coastal Shelf Sci. 2007, 71, 657.

7. de Magalhães, V. F.; Soares, R. M.; Azevedo, S. M. F. O.; Toxicon 2001, 39, 1077.

8. Barcellos, C. C.; Fernandes, H. M.; Azevedo, H. L. P.; Sci. Total Environ. 1988, 75, 211.

9. de Magalhães, L.; Noyma, N. P.; Furtado, L. L.; Mucci, M.; van Oosterhout, F.; Huszar, V. L. M.; Marinho, M. M.; Lürling, M.; Estuaries Coasts 2017, 40, 121.

10. Venkiteshwaran, K.; McNamara, P. J.; Mayer, B. K.; Sci. Total Environ. 2018, 644, 661.

11. Morse, G. K.; Brett, S. W.; Guy, J. A.; Lester, J. N.; Sci. Total Environ. 1998, 212, 69.

12. Xie, J.; Wang, Z.; Lu, S.; Wu, D.; Zhang, Z.; Kong, H.; Chem. Eng. J. 2014, 254, 163.

13. Huser, B. J.; Egemose, S.; Harper, H.; Hupfer, M.; Jensen, H.; Pilgrim, K. M.; Reitzel, K.; Rydin, E.; Futter, M.; Water Res. 2016, 97, 122.

14. Huser, B. J.; Water Res. 2012, 46, 4697.

15. Zhu, M.; Ding, K.; Xu, S.; Jiang, X.; J. Hazard. Mater. 2009 , 165,645 .

16. Wan, J.; Jiang, X.; Zhang, T. C.; Hu, J.; Richter-Egger, D.; Feng, X.; Zhou, A.; Tao, T.; Chemosphere 2018, 196, 153.

17. Xue, R.; Xu, J.; Gu, L.; Pan, L.; He, Q.; Water, Air, Soil Pollut. 2018, 229, 161.

18. Cardwell, A. S.; Adams, W. J.; Gensemer, R. W.; Nordheim, E.; Santore, R. C.; Ryan, A. C.; Stubblefield, W. A.; Environ. Toxicol. Chem. 2018, 37, 36.

19. Nogaro, G.; Burgin, A. J.; Schoepfer, V. A.; Konkler, M. J.; Bowman, K. L.; Hammerschmidt, C. R.; Environ. Pollut. 2013, 176, 267.

20. Gensemer, R. W.; Playle, R. C.; Crit. Rev. Environ. Sci. Technol. 1999, 29:4, 315.

21. Egemose, S.; Wauer, G.; Kleeberg, A.; Hydrobiologia 2009, 636, 203.

22. Zhou, C. H.; Keeling, J.; Appl. Clay Sci. 2013, 74, 3. 
23. Zhu, R.; Chen, Q.; Zhou, Q.; Xi, Y.; Zhu, J.; He, H.; Appl. Clay Sci. 2016, 123, 239.

24. Haghseresht, F.; Wang, S.; Do, D. D.; Appl. Clay Sci. 2009, 46, 369.

25. Zamparas, M.; Gianni, A.; Stathi, P.; Deligiannakis, Y.; Zacharias, I.; Appl. Clay Sci. 2012, 62-63, 101.

26. Reitzel, K.; Andersen, F. T.; Egemose, S.; Jensen, H. S.; Water Res. 2013, 47, 2787.

27. Spears, B. M.; Lürling, M.; Yasseri, S.; Castro-Castellon, A. T.; Gibbs, M.; Meis, S.; McDonald, C.; McIntosh, J.; Sleep, D.; Van Oosterhout, F.; Water Res. 2013, 47, 5930.

28. Kuroki, V.; Bosco, G. E.; Fadini, P. S.; Mozeto, A. A.; Cestari, A. R.; Carvalho, W. A.; J. Hazard. Mater. 2014, 274, 124.

29. Copetti, D.; Finsterle, K.; Marziali, L.; Stefani, F.; Tartari, G.; Douglas, G.; Reitzel, K.; Spears, B. M.; Winfield, I. J.; Crosa, G.; D’Haese, P.; Yasseri, S.; Lürling, M.; Water Res. 2016, 97, 162.

30. Kurzbaum, E.; Shalom, O. B.; Appl. Clay Sci. 2016, 123, 182.

31. Li, H.; Ru, J.; Yin, W.; Liu, X.; Wang, J.; Zhang, W.; J. Hazard. Mater. 2009, 168, 326.

32. Ross, G.; Haghseresht, F.; Cloete, T. E.; Harmful Algae 2008 , 7,545 .

33. Waajen, G.; van Oosterhout, F.; Lürling, M.; Environ. Pollut. 2017, 230, 911.

34. Balusamy, B.; Taştan, B. E.; Ergen, S. F.; Uyar, T.; Tekinay, T.; Environ. Sci.: Processes Impacts 2015, 17, 1265.

35. He, J.; Wang, W.; Sun, F.; Shi, W.; Qi, D.; Wang, K.; Shi, R.; Cui, F.; Wang, C.; Chen, X.; ACS Nano 2015, 9, 9292.

36. Xie, R.; Chen, Y.; Cheng, T.; Lai, Y.; Jiang, W.; Yang, Z.; Water Sci. Technol. 2016, 3, 1891.

37. ASTM C837-09: Standard Test Method for Methylene Blue Index of Clay, ASTM International, West Conshohocken, PA, 2014.

38. Neves, L. E.; Bol. Tec. PETROBRAS 1968, 11, 123.

39. Anantha, R. K.; Kota, S.; Environ. Technol. Innovation 2016 , $6,11$.

40. Ho, Y. S.; Ng, J. C. Y.; McKay, G.; Sep. Purif. Methods 2000, 29, 189.

41. Blanchard, G.; Maunaye, M.; Martin, G.; Water Res. 1984, 18, 1501.

42. Ho, Y. S.; McKay, G.; Process Saf. Environ. Prot. 1998, 76, 332.

43. Ho, Y. S.; J. Hazard. Mater. 2006, 136, 681.

44. Tran, H. N.; You, S. J.; Hosseini-Bandegharaei, A.; Chao, H. P.; Water Res. 2017, 120, 88.

45. American Public Health Association (APHA); American Water Works Association (AWWA); Water Environment Federation (WEF); Standard Methods for the Examination of Water and Wastewater; APHA: Washington, DC, USA, 1992, p. 4-108.

46. Google Earth Pro, version 7.3.1.4507 (64-bit); Google, USA, 2018.
47. https://www.google.com.br/maps/place/22 $2^{\circ} 59^{\prime} 01.6 \% 22 \mathrm{~S}+43^{\circ}$ 23’35.5\%22W, accessed on March 12, 2018.

48. Alves, J. L.; Zanini, A. E.; de Souza, M. E.; Nascimento, M. L. F.; Cerâmica 2016, 62, 1.

49. Kutlić, A.; Bedeković, G.; Sobota, I.; Rud.-Geol.-Naftni Zb. 2012, 24, 61.

50. Hayakawa, T.; Minase, M.; Fujita, K. I.; Ogawa, M.; Clays Clay Miner. 2016, 64, 275.

51. Choo, K. Y.; Bai, K.; Appl. Clay Sci. 2016, 126, 153.

52. Ahonen, L.; Korkeakoski, P.; Tiljander, M.; Kivikoski, H.; Laaksonen, R.; Working Report 2008-33, Quality Assurance of the Bentonite Material; Posiva Oy: Olkiluoto, Eurajoki, Finland, 2008.

53. Kahr, G.; Madsen, F. T.; Appl. Clay Sci. 1995, 9, 327.

54. Lavikainen, L. P.; Tanskanen, J. T.; Schatz, T.; Kasa, S.; Pakkanen, T. A.; Theor. Chem. Acc. 2015, 134, 51.

55. Lavikainen, L.; The Structure and Surfaces of 2:1 Phyllosilicate Clay Minerals, vol. 137; University of Eastern Finland: Joensuu, Finland, 2016.

56. Djomgoue, P.; Njopwouo, D.; J. Surf. Eng. Mater. Adv. Technol. 2013, 3, 275.

57. Conselho Nacional do Meio Ambiente (CONAMA); Resolução No. 357, de 17 de março de 2005, Dispõe sobre a Classificação dos Corpos de Água e Diretrizes Ambientais para o seu Enquadramento, bem como Estabelece as Condições e Padrões de Lançamento de Efluentes, e Dá Outras Providências; DOU: Brasília, Brasil, 2005, No. 053, p. 58-63.

58. Anastopoulos, I.; Bhatnagar, A.; Lima, E. C.; J. Mol. Liq. 2016, $221,954$.

59. Lewtas, K.; Paterson, M.; Venema, H. D.; Roy, D.; Manitoba Prairie Lakes: Eutrophication and In-Lake Remediation Treatments; International Institute for Sustainable Development: Winnipeg, Canada, 2015.

60. Lürling, M.; Van Oosterhout, F.; Water Res. 2013, 47, 6527.

61. Tian, S.; Jiang, P.; Ning, P.; Su, Y.; Chem. Eng. J. 2009, 151, 141.

62. Vianna, M. T. G.; Marques, M.; Bertolino, L. C.; Ecol. Eng. 2016, 97, 13.

63. Mucci, M.; Maliaka, V.; Noyma, N. P.; Marinho, M. M.; Lürling, M.; Sci. Total Environ. 2018, 619-620, 1431.

64. Amorim, L. V.; Gomes, C. M.; Lira, H. L.; França, K. B.; Ferreira, H. C.; Mater. Res. 2004, 7, 583.

65. Baltar, C. A. M.; Bastos, F. F.; da Luz, A. B.; Rochas e Minerais Industriais; CETEM-MCT: Rio de Janeiro, 2005.

66. Silva, A. R. V.; Ferreira, H. C.; Rev. Eletrônica Mater. Processos 2008, 3, 26.

Submitted: September 8, 2018 Published online: December 5, 2018 